\title{
Understanding Dynamic Conditional Correlations between Oil, Natural Gas and Non-Energy Commodity Futures Markets
}

\author{
Niaz Bashiri Behmiri, * Matteo Manera, ** and Marcella Nicolini***
}

\begin{abstract}
We look at the dynamic conditional correlations (DCCs) between oil, natural gas and other non-energy commodity futures markets, obtained from a DCC-GARCH model over the period 1998-2014. They are positive and display a sharp increase around year 2008 and a subsequent decrease. The DCCs between energy and metals are larger than the energy-agriculture ones. To understand how macroeconomic and financial factors, as well as speculative activity, influence them, we estimate an ARDL(1,1) model, adopting a pooled mean group (PMG) estimator. We observe that macroeconomic and financial variables are significantly correlated with the energy-agriculture and energy-metals DCCs. Speculative activity contributes to explain the energy-agriculture DCCs but not those of the energy-metals.
\end{abstract}

Keywords: Multivariate GARCH, Dynamic conditional correlations, Pooled mean group, Commodity futures markets, Oil, Natural gas, Agriculture, Metals.

https://doi.org/10.5547/01956574.40.2.nbeh

\section{INTRODUCTION}

The links between energy and non-energy commodity futures markets have deepened in recent times: the liberalization of capital flows, the development in market trading technologies and in new financial instruments, and the improvement in information transmission have all contributed to an increased integration between commodity markets (Ji and Fan, 2012). After the equity market collapse in 2000, commodities became an increasingly popular asset class, eligible for portfolio diversification, thanks to the negative correlation between commodity futures returns and stock returns (Gorton and Rouwenhorst, 2006). ${ }^{1}$ Furthermore, the boom of biofuels in the 2000s increased the links between energy and some agricultural markets (FAO, 2008).

Basak and Pavlova (2016) show theoretically that the correlations between commodity futures, as well as the equity-commodity correlations, increase with the financialization of these commodity markets. In recent years, empirical analysis reports an increase in the correlations between commodities, which might therefore have limited the benefits of a diversification strategy from equity to commodity futures markets (Cheung and Miu, 2010; Daskalaki and Skiadopoulos, 2011). As volatilities spillover across markets, knowledge of these dynamics is crucial for investors and financial institutions in terms of portfolio construction and risk management. Investigating the

1. Cheng and Xiong (2014) provide a comprehensive overview of the different channels through which financialization has affected commodity markets.

* University of Stavanger Business School, Stavanger, Norway. E-mail: niaz.bashiribehmiri@uis.no

** Corresponding author. University of Milan-Bicocca, Milan; Ipag Business School, Paris; Fondazione Eni Enrico

Mattei, Milan; EfeLab, University of Milan. E-mail: matteo.manera@unimib.it.

*** University of Pavia, Pavia. E-mail: marcella.nicolini@unipv.it 
dynamics of the correlations between these markets is essential to develop accurate asset pricing models and hedging strategies, as well as to minimize the contagion risk in the occurrence of a crash in one of these markets (Baruník et al., 2015).

Several authors have recently focused on the linkages between commodities futures markets, looking at the time-varying correlations produced through different multivariate GARCH specifications. With respect to the volatilities and correlations between energy and agricultural futures markets, researchers find statistically significant volatility spillovers from oil to agricultural markets, with a change in the dynamics of volatility transmission after the second half of the 2000s. These results are obtained using different methodologies, such as bivariate EGARCH (Ji and Fan, 2012), bivariate stochastic volatility models (Du et al., 2011), and the VAR-BEKK-GARCH and VAR-DCC-GARCH models (Mensi et al., 2014). Some authors focus in particular on the agriculture-ethanol-fossil fuels link, which has had a great deal of attention from the early 2000s. Adopting multivariate GARCH models, they find strong volatility linkages, both in the U.S. and in the emerging markets (Chang and Su, 2010; Serra, 2011; Wu et al., 2011; Du and McPhail, 2012; Trujillo-Barrera et al., 2012; Gardebroek and Hernandez, 2013; Wu and Li, 2013).

Another area that has attracted much interest in the last decade is the relationship between energy commodities and metals. This relationship is far from simple, with metals being traded for both industrial use and hedging strategies. As for the spillovers between metal and energy markets, significant transmission of volatility between metals and oil prices is found using different methodologies such as the Markov-switching space state model (Choi and Hammoudeh, 2010), univariate and bivariate GARCH (Ewing and Malik, 2013), and the Hidden Markov Decision Tree (Charlot and Marimoutou, 2014).

These papers do not, however, investigate under which circumstances these correlations change. Indeed, a number of studies investigate the effects of macroeconomic and financial factors on the volatility of commodity futures returns (Hammoudeh and Yuan, 2008; Batten et al., 2010; Sanders and Irwin, 2011; Irwin and Sanders, 2012; Manera et al., 2016). However, with respect to time-varying correlations, the literature so far has investigated the factors affecting the correlations between commodities and stock markets (Silvennoinen and Thorp, 2013; Büyükşahin and Robe, 2014), or those between energy futures returns (Karali and Ramirez, 2014; Bunn et al., 2017).

Silvennoinen and Thorp (2013) find that the correlations between stocks, bonds and commodity futures returns have increased for most commodities, often when the VIX volatility index was high, thus pointing to strong financial influences. Their results are consistent with the analysis of Cheung and Miu (2010) and Daskalaki and Skiadopoulos (2011). Büyükşahin and Robe (2014) concentrate on the role of financialization in commodity markets on stock-commodity co-movement, and show that the speculative activity of hedge funds that trade actively in both equity and commodity future markets has explanatory power for the correlation between stocks and commodities. The predictive power of the speculative activity is, however, weaker in periods of higher stress in the financial markets. Karali and Ramirez (2014) analyze the time-varying volatility and spillover effects in energy futures markets, finding that macroeconomic variables and political and weather-related events have an effect on the volatilities and their correlations. More recently, Bunn et al. (2017) have provided evidence that the strength of the speculative activity is an important determinant of co-movements between oil and gas returns, even once fundamentals have been taken into account.

Overall, the empirical evidence on the factors which influence the time-varying correlations between energy and non-energy commodities futures markets is lagging behind. The drivers of these correlation patterns over time are a field still not explored, but important to understanding 
whether the diversification benefits of commodities to equity market investors have weakened or not. From a public policy perspective, it is relevant to understand whether dynamic conditional correlations between commodities respond to monetary policies.

We provide fresh evidence to fill this gap in the literature. To the best of our knowledge, this is the first attempt to investigate these correlations within a unique framework: i.e. with a common methodology to obtain the time-varying correlations, looking at the same period of analysis, and considering common explanatory variables, thus allowing a direct comparison of the results found across different sets of commodities.

First, we estimate a dynamic conditional correlation (DCC) multivariate GARCH (Engle, 2002), which allows for covariance and correlation spillovers. The analysis considers ten commodities at weekly frequency: West Texas Intermediate (WTI) crude oil and natural gas; five agricultural commodities (corn, oats, rice, soybeans, and wheat); and three metals (copper, gold, and silver) over the period spanning from 1998:w1 to 2014:w22. We observe that the correlations between energy and metals futures markets are larger than those between energy and agricultural commodities. The DCCs peaked around the 2008 financial crisis and subsequently decreased.

We then investigate under which circumstances energy and non-energy commodities futures returns display larger dynamic conditional correlations. We consider macroeconomic fundamentals, financial market characteristics and speculative activity, following the prior literature that suggests these factors might matter for commodity futures returns correlations. We estimate an Autoregressive Distributed Lag (ARDL) model by means of the Pooled Mean Group (PMG) estimator (Pesaran et al., 1999). Our analysis suggests that macroeconomic and financial factors influence the agriculture-energy and metals-energy correlations. Speculative activity in the energy markets is significant in explaining correlations with agricultural commodities, but not those with metals.

The paper is structured as follows: Section 2 focuses on the first step of our analysis: namely, retrieving the DCCs, by discussing the data, the methodology, and the characteristics of the DCCs we obtain. Section 3 concerns the second step of the econometric analysis: understanding these correlations. It describes the explanatory variables, the econometric specification and presents the results, as well as some robustness checks. Finally, Section 4 concludes.

\section{OBTAINING THE DCCS BETWEEN COMMODITIES FUTURES MARKETS}

\subsection{Data description: Commodity futures returns}

We develop our analysis on a sample of ten commodities futures belonging to three different industries: energy (West Texas Intermediate (WTI) crude oil and natural gas); agriculture (corn, oats, rice, soybeans, and wheat), and metals (copper, gold, and silver). We collect data at weekly frequency for the period ranging from 1998:w1 to 2014:w22.

The weekly price series for these commodities are obtained by rolling over their first nearby contracts on the second Thursday of the maturity month. The returns are computed as $r_{i t}=\log \left(\frac{P_{i t}}{P_{i t-1}}\right)$, where $r_{i t}$ is the corresponding return, $P_{i t}$ is the weekly future real price, obtained by subtracting realized inflation, calculated from the U.S. consumer price index (CPI), base year 2010, from the

2. Energy commodities are traded on the New York Mercantile Exchange (NYMEX), agricultural commodities on the Chicago Board of Trade (CBOT), and metals on the Commodity Exchange Market (COMEX). 
Table 1: Descriptive statistics for commodity futures returns

\begin{tabular}{|c|c|c|c|c|c|c|}
\hline & \multicolumn{3}{|c|}{ Summary statistics } & \multirow{2}{*}{$\frac{\text { Unit root test }}{\text { Augmented Dickey-Fuller }}$} & \multicolumn{2}{|c|}{ Residual diagnostics } \\
\hline & Mean & Skewness & Kurtosis & & $\mathrm{ARCH}$ & Breusch-Godfrey \\
\hline Corn & 0.000 & -0.012 & 5,241 & $-36.59 * * *$ & $3.84 * *$ & 1.39 \\
\hline Soybeans & 0.000 & -0.510 & 6,200 & $-36.22 * * *$ & $27.87 * * *$ & 0.62 \\
\hline Wheat & 0.000 & 0.208 & 3,791 & $-35.81 * * *$ & $23.44 * * *$ & 0.17 \\
\hline Oats & 0.001 & -0.238 & 6,672 & $-37.71 * * *$ & $8.43 * *$ & $4.94 * *$ \\
\hline Rice & 0.000 & -0.240 & 7,932 & $-34.26 * * *$ & $6.07 * *$ & 1.4 \\
\hline Copper & 0.001 & -0.263 & 5,403 & $-34.32 * * *$ & $25.42 * * *$ & 1.28 \\
\hline Gold & 0.001 & 0.075 & 7,747 & $-35.44 * * *$ & $3.93 * *$ & 0.00 \\
\hline Silver & 0.001 & -0.477 & 6,491 & $-35.61 * * *$ & $40.70 * * *$ & 0.036 \\
\hline WTI & 0.002 & -0.499 & 5,446 & $-40.91 * * *$ & $38.70 * * *$ & $20.52 * * *$ \\
\hline NG & 0.000 & 0.159 & 3,656 & $-36.21 * * *$ & $5.41 * * *$ & 0.61 \\
\hline
\end{tabular}

Notes: $* * *$ and $* *$ indicate statistical significance at the $1 \%$ and $5 \%$ levels, respectively.

nominal price; $i=1 \ldots 10$ defines the commodity futures market; and $t$ is the week. Table 1 reports the descriptive statistics for the commodities futures returns. ${ }^{3}$

As a first check, we test the stationarity of the commodity futures returns. The augmented Dickey Fuller (1979) unit root test confirms the stationarity of all returns at the $1 \%$ significance level. Then, we inspect the residuals obtained from the OLS regression of each series of returns on a constant term. The Lagrange multiplier test suggests the existence of the ARCH effects for all returns at the $1 \%$ and $5 \%$ levels of significance. The Breusch-Godfrey test for higher-order serial correlation in the disturbance provides evidence of serial correlation for oats and WTI, while no serial correlation is detected for the other commodities.

\subsection{Methods: The multivariate GARCH}

Commodity futures volatilities are known to move together over time across markets, thus a multivariate framework is the best way to model this feature (Bauwens et al., 2006). Multivariate GARCH models allow us to evaluate the dynamics of volatilities and co-volatilities across commodities markets. Furthermore, by producing correlations between commodity futures returns that are time-varying, they allow us to investigate their evolution over time and under which circumstances they increase. Indeed, the analysis of the time-varying correlation patterns is relevant to understand how the benefits of the diversification strategies into commodity futures markets have changed over time (Silvennoinen and Thorp, 2013).

The preliminary tests reported in Table 1 suggest that we can model the volatilities of the ten commodities with a multivariate GARCH model. We opt for a DCC-GARCH model (Engle, 2002). This approach captures the effects on the current volatility of own innovation and lagged volatility shocks originating in a given market, and allows for covariance and correlation spillovers from other futures markets. Thus, it is suitable to investigate volatility in interconnected markets. The general multivariate GARCH model is defined as:

$$
\begin{aligned}
& r_{t}=C x_{t}+\varepsilon_{t} \\
& \varepsilon_{t}=H_{t}^{1 / 2} v_{t} \\
& H_{t}=D_{t}^{1 / 2} R_{t} D_{t}^{1 / 2}
\end{aligned}
$$

3. The correlation matrix for commodity futures returns is reported in Table A.1 in the online Appendix. 
where $r_{t}$ is a $10 \mathrm{x} 1$ vector of ten commodities returns; $\mathrm{C}$ is an $10 \mathrm{x} k$ matrix of parameters; and $x_{t}$ is a $k \times 1$ vector of covariates, which contains a constant and, if necessary to remove autocorrelation, an $\mathrm{AR}(1)$ term. The error term is defined by $H_{t}^{1 / 2}$, the Cholesky factor of the time-varying conditional covariance matrix of the disturbances $H_{t}$ times $v_{t}$, a $10 \mathrm{x} 1$ vector of i.i.d. innovations with zero mean and unit variance. $D_{t}$ is a diagonal matrix of conditional variances, in which each $\sigma_{i t}^{2}$ evolves according to a univariate $\operatorname{GARCH}(1,1)^{4}$ process, which is defined as:

$$
\begin{aligned}
& \sigma_{i t}^{2}=s_{i}+\alpha \varepsilon_{i t-1}^{2}+\beta \sigma_{i t-1}^{2} . \\
& R_{t}=\operatorname{diag}\left(Q_{t}\right)^{-1 / 2} Q_{t} \operatorname{diag}\left(Q_{t}\right)^{-1 / 2}
\end{aligned}
$$

where $R_{t}$ is a matrix of time-varying conditional quasi correlations, which is not explicitly driven by a dynamic equation, but is derived from a standardization of $Q_{t}$. The form of $Q_{t}$ determines the complexity and feasibility of the model (Caporin and McAleer, 2012). We adopt the following specification:

$$
Q_{t}=\left(1-\lambda_{1}-\lambda_{2}\right) R+\lambda_{1} \tilde{\varepsilon}_{t-1} \tilde{\varepsilon}_{t-1}^{\prime}+\lambda_{2} Q_{t-1}
$$

where $R$ is the long-run solution of the MGARCH model, i.e. $R$ is the unconditional expectation of the dynamic conditional correlation matrix $R_{t} ; \tilde{\varepsilon}_{t}$ is a 10 x 1 vector of standardized residuals $\left(D_{t}^{-1 / 2} \varepsilon_{t}\right)$; and $\lambda_{1}$ and $\lambda_{2}$ are the two parameters that determine the dynamics of conditional quasi correlations. They are both non-negative, and they must satisfy the condition: $0 \leq \lambda_{1}+\lambda_{2}<1$. When $Q_{t}$ is stationary, the $R$ matrix is a weighted average of the unconditional covariance matrix of the standardized residuals $\tilde{\varepsilon}_{t}$ and the unconditional mean of $Q_{t}{ }^{5}$

While the DCC has the advantage of generating all the dynamic conditional correlations from a common setting, it assumes that these correlation dynamics are driven by the same $\lambda_{1}$ and $\lambda_{2}$ parameters. A common alternative, which is more flexible in this respect, is the BEKK model (Engle and Kroner, 1995). The most attractive features of the DCC model over the BEKK in the present context is that it allows us to directly infer the time-varying correlations between commodities futures markets. Additionally, it easily deals with a relatively large number of variables in the system: indeed, with ten commodities a DCC requires 47 parameters to be estimated for the covariance matrix, as opposed to 75 with a diagonal BEKK, or 255 with a BEKK. ${ }^{6}$ For a thorough discussion of the advantages and disadvantages of the DCC model over the BEKK model in empirical applications, see Caporin and McAleer (2012). ${ }^{7}$

A further alternative could be the DCC-MIDAS model (Colacito et al., 2011), which is the extension of the univariate GARCH-MIDAS (Engle et al., 2013) to a multivariate DCC model. The advantage of the GARCH-MIDAS approach is that it extracts the short- and long-run components

4. We choose a $\operatorname{GARCH}(1,1)$ specification, as higher orders of lags of $\varepsilon^{2}$ and $\sigma^{2}$ are not significant.

5. As the two matrices are different, the $R$ matrix is neither the unconditional correlation matrix, nor the unconditional mean of $Q_{t}$. As a consequence, the parameters in $R$ are known as quasi correlations (Engle, 2009).

6. The number of parameters discussed does not include the univariate GARCH parameters: namely $3 k$ at a minimum, a number which does not change across the alternative modeling choices presented. See Table 1 in Caporin and McAleer (2012).

7. As an alternative check on the assumption of common parameters $\lambda_{1}$ and $\lambda_{2}$, we run bivariate DCCs, finding that the estimated DCCs we obtain are correlated on average 0.84 with the DCCs from the system with ten commodities. Thus, imposing the same set of parameters that determine the dynamics of conditional quasi correlations across ten commodities does not strongly affect the results. 
of volatility ${ }^{8}$ and allows the extracted mixed-data sampling component to be explicitly inked to macroeconomic or financial variables, thus avoiding the generated regressors problem (Pagan, 1984) typical of a two-step methodology. In the DCC-MIDAS approach the daily dynamics follow a DCC model, and correlations move around a long-run component, which can be linked to macroeconomic and financial variables. ${ }^{9}$

However, such a methodology has shortcomings that prevent its adoption in the present context. Indeed, our explanatory variables, as will be discussed in Section 3.1, are available at weekly frequency. The ratio of daily to weekly frequencies is not large enough to estimate weekly realized volatility. Ignoring uncertainty from the generated regressors obtained in the first step of our approach is less harmful than the uncertainty generated from using a DCC-MIDAS model to estimate weekly realized volatility using only five trading days per week.

\subsection{Results: DCC-GARCH estimation and the dynamic conditional correlations}

Table 2 shows the results of the DCC-GARCH model. As the preliminary tests reported in Table 1 detected the presence of serial correlation in the returns series of oats and WTI, we include a first-order autoregressive term, $\mathrm{AR}(1)$, in their mean equation.

The variance equations show that the estimates for $\alpha$ are generally smaller than they are for the $\beta$ coefficients, suggesting that a shock in the volatility series impacts on futures volatility over a long period. The $\alpha$ and $\beta$ parameters are non-negative and sum to less than 1, and thus the necessary conditions for covariance stationarity are met. Additionally, $\lambda_{1}$ and $\lambda_{2}$ are positive and statistically different from 0 , confirming that the conditional correlations we observe are dynamic, and that the assumption of time-invariant conditional correlations would be too restrictive. Their sum is less than 1 , ensuring that the second moments are stationary too.

As a robustness check, we compare the correlations obtained from the DCC reported in Table 2 with those from a BEKK model. By simply looking at the series, we observe that the time-varying correlations obtained from a BEKK are correlated 0.91 with the dynamic conditional correlations from the DCC model presented. ${ }^{10}$

This model produces a panel of 45 dynamic conditional correlations over the period 19982014. To graphically inspect the evolution of these correlations over time, we report the unweighted average of the 45 dynamic conditional correlations obtained, as well as the unweighted average of the ten energy-agriculture correlations and that of the six energy-metals correlations in Figure 1.

The conditional correlations are positive and definitely time-varying. While the correlations have been rather stable in the first half of the time span considered, they display a stunning increase around the beginning of 2008 , which could be the result of the general spike in commodities

8. The short-run component comes from a mean-reverting daily GARCH process and moves around a long-run component driven by realized volatilities computed on a monthly, quarterly, or biannual basis. The slowly moving component is extracted by means of a mixed-data sampling (MIDAS) weighting scheme.

9. More precisely, short-lived effects on correlations are captured by the autoregressive dynamic structure of DCCs, with the intercept of the latter being a slowly moving process that reflects the fundamental or long-run causes of time variation in correlations (Colacito et al., 2011).

10. We also estimate the DCC model assuming that the errors come from a multivariate Student $t$ distribution. The correlation coefficient between the dynamic conditional correlations obtained from this specification and those obtained assuming a multivariate normal distribution is 0.99 . The results for the DCC with a Student $t$ distribution and the BEKK model are not reported but are available from the authors on request. 


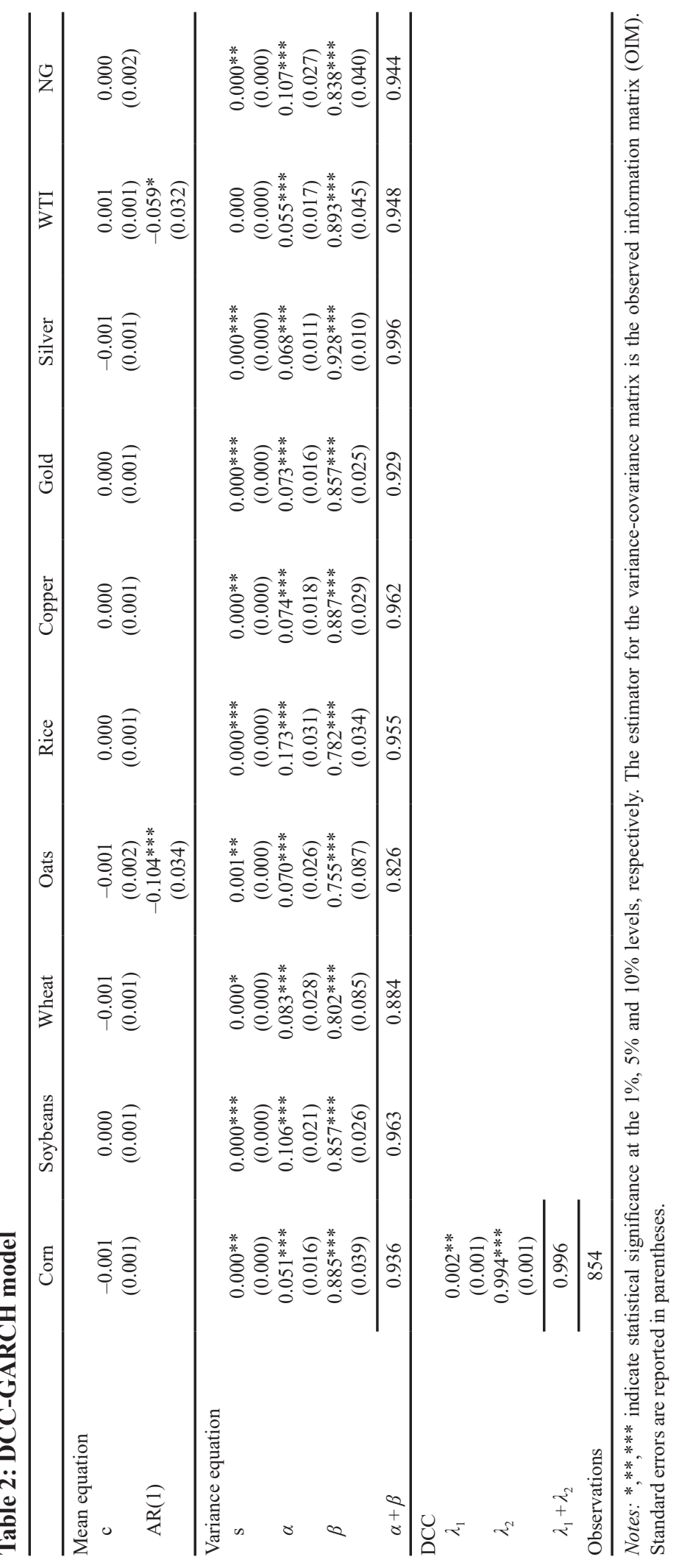


Figure 1: Dynamic conditional correlations

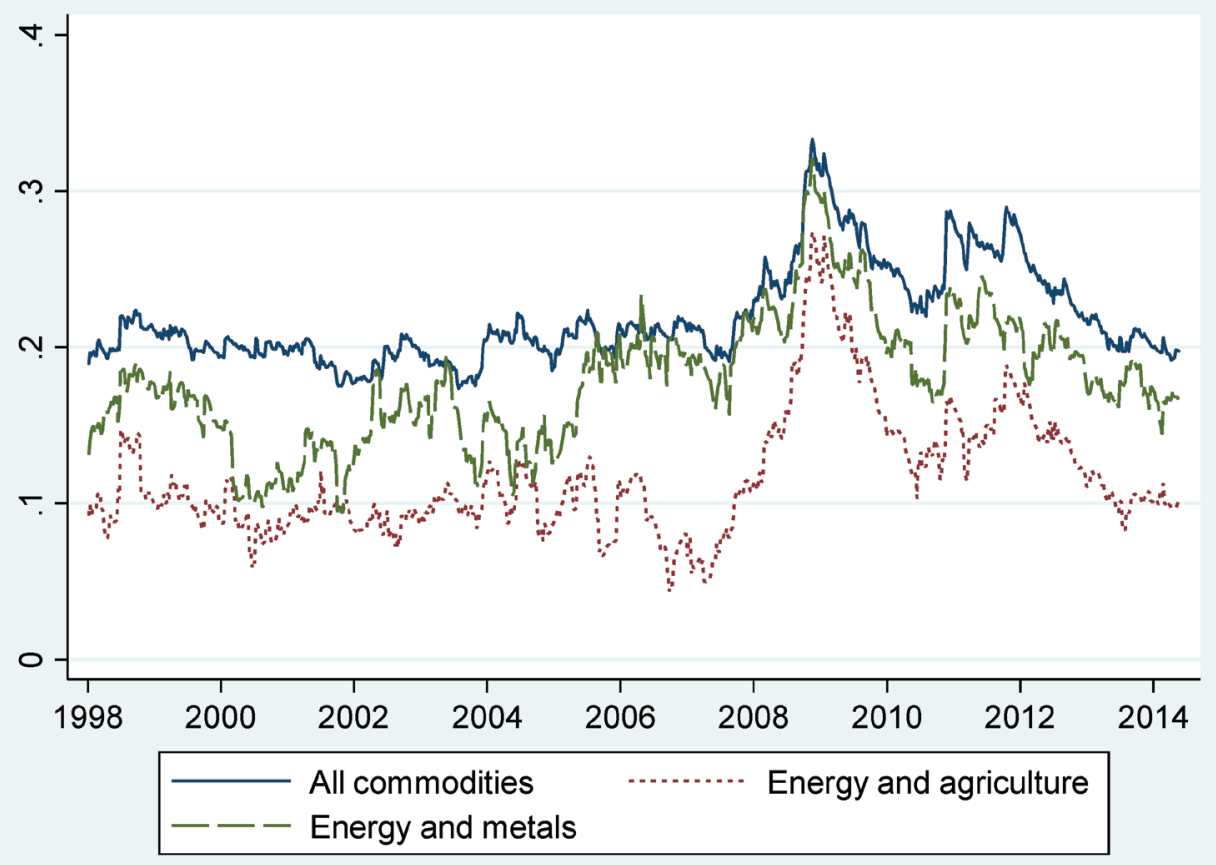

prices. In November 2008 the pooled correlations reached an average value of 0.327 . Correlations subsequently decreased to revert to comparable levels at the end of our period of investigation. ${ }^{11}$

If we focus on the correlations between energy and the other class of commodities, we observe that they share a similar trend over time. However, the DCCs between energy and metal commodities are generally higher than those between energy and agricultural commodities, with average values equal to 0.179 and 0.116 , respectively, over the whole time span considered. Moreover, they are more dispersed, as displayed by the cross-sectional standard deviations reported in Table 3 .

Table 3 shows some additional descriptive statistics on the DCCs, as well as the Levin-LinChu (2002) panel unit root tests, which reject the presence of a unit root in the panels of dynamic conditional correlations that will be considered further in Section 3. The descriptive statistics reported confirm that mean and standard deviations increased after 2008 for the whole set of DCCs, as well as for the two subsamples of interest. The evidence provided so far is consistent with the findings by Silvennoinen and Thorp (2013) and Mensi et al. (2014). To further investigate under which circumstances these DCCs change, we move to the second step of our analysis.

\section{UNDERSTANDING THE BEHAVIOUR OF THE DCCS}

\subsection{Data: The explanatory variables}

This second step of the empirical analysis is devoted to understanding what is the relationship between some factors that are widely acknowledged to be related to the volatilites of commod-

11. We further investigate these differences by splitting the analysis before and after the year 2008. This allows us to analyze these two periods separately, as they display different dynamics. The results are discussed in the online Appendix, and are reported in Tables A.5 and A.6. 
Table 3: Descriptive statistics for the panel of DCCs

\begin{tabular}{|c|c|c|c|c|c|c|c|}
\hline & Obs & Mean & Std. Dev. & $\begin{array}{l}\text { Cross-sectional } \\
\text { Std. Dev. }\end{array}$ & Min & Max & LLC \\
\hline \multicolumn{8}{|l|}{$1998-2014$} \\
\hline all commodities & 855 & 0.219 & 0.031 & 0.150 & 0.174 & 0.333 & $-5.665 * * *$ \\
\hline energy-agriculture & 855 & 0.116 & 0.040 & 0.060 & 0.044 & 0.274 & $-2.136^{* *}$ \\
\hline energy-metals & 855 & 0.179 & 0.041 & 0.105 & 0.094 & 0.321 & $-2.909 * * *$ \\
\hline \multicolumn{8}{|l|}{ 1998-2007 } \\
\hline all commodities & 521 & 0.201 & 0.011 & 0.151 & 0.174 & 0.224 & $-6.070 * * *$ \\
\hline energy-agriculture & 521 & 0.095 & 0.018 & 0.058 & 0.044 & 0.148 & $-2.981 * * *$ \\
\hline energy-metals & 521 & 0.158 & 0.030 & 0.095 & 0.094 & 0.233 & $-2.633 * * *$ \\
\hline \multicolumn{8}{|l|}{$2008-2014$} \\
\hline all commodities & 334 & 0.247 & 0.032 & 0.148 & 0.192 & 0.333 & $-2.692 * * *$ \\
\hline energy-agriculture & 334 & 0.150 & 0.042 & 0.062 & 0.083 & 0.274 & $-3.229 * * *$ \\
\hline energy-metals & 334 & 0.210 & 0.035 & 0.122 & 0.144 & 0.321 & $-1.867 * *$ \\
\hline
\end{tabular}

Notes: The cross-sectional standard deviation is the standard deviation of DCCs for different commodities for a given week $t$. The values reported are the averages of these cross-sectional standard deviations over different time periods and different subsamples of DCCs. We report the Levin-Lin-Chu (2002) bias-adjusted test statistic. *,**,*** denote statistical significance at the $1 \%, 5 \%$ and $10 \%$ levels, respectively.

ities and the dynamic conditional correlations between these commodities. Indeed, it is relevant to understand under which circumstances the dynamic conditional correlations between energy and non-energy commodity futures markets are larger, for both public policy and financial investment purposes. Thus, we look at the main macroeconomic and financial factors highlighted in the literature, as well as at the speculative activity, as they might affect the behavior of these correlations.

To investigate how the dynamic conditional correlations change along the business cycle, following Büyükşahin and Robe (2014), we use the Aruoba-Diebold-Scotti (ADS) business conditions index (Aruoba et al., 2009). The $A D S$ is designed to track the real business conditions of the U.S. economy, and weekly data are obtained from the Federal Reserve Bank of Philadelphia. ${ }^{12}$

The short-term interest rate and the yield spread are known to predict the common variation in commodity, bond, and stock returns (Bessembinder and Chan, 1992; Büyükşahin and Robe 2014). From a public policy perspective, it is relevant to understand whether dynamic conditional correlations between commodities respond to changes in monetary policy. To this aim, we use the real three-month Treasury bill interest rate, obtained by subtracting realized inflation rate, calculated from the U.S. consumer price index (CPI), base year 2010, from the nominal interest rate supplied by the Federal Reserve Bank of St. Louis (FRED) at weekly frequency.

Following Hong and Yogo (2012), we define the yield spread as the difference between Moody's seasoned AAA corporate bond yield and the three-months Treasury yield. This index captures what happens when the difference between a long-term unsecured yield, which mirrors the stability of the industrial sector, and a short-term secured yield, which reflects the current government monetary policy, arises. We obtain this data from the Federal Reserve Bank of St. Louis (FRED) at weekly frequency.

We also consider the trade weighted U.S. Dollar Index, provided by FRED, which is a weighted average of the foreign exchange value of the U.S. dollar against the currencies of a broad group of major U.S. trading partners.

Additionally, to account for the role of volatility in the financial markets, we include the Chicago Board Options Exchange (CBOE) Volatility Index (VIX).

12. The average value of the $A D S$ index is zero, with positive values corresponding to better-than-average macroeconomic conditions and negative values to worse-than-average ones. 
To understand whether a greater presence of speculators affects the dynamic conditional correlations between commodities futures, we proxy speculative activity using the Working's (1960) $\mathrm{T}$ index. This index measures excess speculation, i.e. to what extent speculative positions exceed hedging ones, and is computed as:

$$
W T= \begin{cases}1+\frac{S S}{H S+H L} & \text { if } H S \geq H L \\ 1+\frac{S L}{H S+H L} & \text { if } H S<H L\end{cases}
$$

where SS is speculation short; SL is speculation long; HS is hedging short; and HL is hedging long. Therefore, the index presented in (2) is the ratio of speculative positions to total hedgers positions.

Our analysis relies on data obtained from the U.S. Commodity Futures Trading Commission (CFTC).

The CFTC requires large traders holding positions above a specified threshold to report their positions daily. Every Tuesday, it releases the aggregate data on the breakdown of open interest in its Commitments of Traders Report (CoT). This report contains the number of long and short positions for both "commercial" and "non-commercial" traders. The CFTC defines a non-commercial trader as any trader who does not use commodity futures contracts to hedge. Following much of the literature, we attribute positions of non-commercial traders to speculators, as they seek profit by taking positions in the futures market, hoping to gain from changes in the price of the commodity, and do not intend to engage in the physical delivery. "Commercial" traders' positions are attributed to hedgers, as they are typically the producers and consumers of the physical commodity. ${ }^{13}$

As exhaustively discussed in Alquist and Gervais (2013), these definitions are widely accepted and consistent with those used by regulatory agencies. There is, however, an inherent imprecision to be recognized: commercial traders can take speculative positions, while non-commercials can hedge exposure to risk. Thus, the distinction between speculators and hedgers is not clear-cut, as the definitions introduced above assume. We might think of a continuum of choices, with some firms speculating, some hedging, and some doing both. ${ }^{14}$ While we recognize that the definition of speculators and hedgers we adopt might be missing some nuances, we believe that we can pragmatically adopt it by virtue of its feasibility and good approximation of reality.

Finally, we enrich this second step of the econometric analysis with a set of annual and monthly dummies. These dummies are able to control for slow movement dynamics present in the weekly dynamic conditional correlations. Year dummies allow us to control for specific events, i.e. the 2000 and the 2008 crises. Monthly dummies instead catch time-varying characteristics in the series, which could be related to changes in demand and supply. Additionally, monthly dummies may control for seasonality, which can be an issue for energy and agricultural commodities. ${ }^{15}$

13. Besides, CFTC provides data for "Non-Reportable" agents, which are not classified in either of the two groups above: we assign $50 \%$ of them to the speculators and 50\% to the hedgers' group. Any rule to assign these positions to either category is based on some assumption. We could consider them as being all commercials, or all non-commercials. An intermediate and more conservative approach is to classify them as partly commercial positions and partly non-commercial ones. Previous research on these data (see, for instance, Manera et al., 2013) shows that the results are robust across different splitting rules.

14. Along this line of argument, Kilian and Murphy (2014) adopt a much broader definition of speculator, which encompasses anyone buying commodities not for current consumption but for future use. Such a definition would include, e.g. in the case of crude oil, refineries, whose activities might affect the returns of crude oil and correlations with other commodities.

15. See, for example, Suenaga and Smith (2011) on energy markets and Sørensen (2002) on agricultural ones. 
Table 4: Explanatory variables: definition and sources

\begin{tabular}{|c|c|c|}
\hline Variables & Definition & Source \\
\hline$A D S$ & Aruoba-Diebold-Scotti (ADS) business conditions index. & $\begin{array}{l}\text { Federal Reserve Bank of } \\
\text { Philadelphia }\end{array}$ \\
\hline$T B 3$ & Real three-month Treasury bill interest rate (CPI. 2010=100). & $\begin{array}{l}\text { Federal reserve Economic } \\
\text { Data (FRED) }\end{array}$ \\
\hline Spread & $\begin{array}{l}\text { Difference between Moody's seasoned AAA corporate bond yield and the } \\
\text { three months Treasury yield. }\end{array}$ & \\
\hline$E X$ & $\begin{array}{l}\text { Trade weighted U.S. Dollar Index (broad): A weighted average of the foreign } \\
\text { exchange value of the U.S. dollar against the currencies of a broad group } \\
\text { of major U.S. trading partners. The broad currency index includes the Euro } \\
\text { Area, Canada, Japan, Mexico, China, United Kingdom, Taiwan, Korea, } \\
\text { Singapore, Hong Kong, Malaysia, Brazil, Switzerland, Thailand. }\end{array}$ & $\begin{array}{l}\text { Federal reserve Economic } \\
\text { Data (FRED) }\end{array}$ \\
\hline$V I X$ & $\begin{array}{l}\text { The CBOE Volatility Index that shows the market's expectation for the next } \\
\text { 30-day volatility. It is built using the implied volatilities of a wide range of } \\
\text { S\&P } 500 \text { index options. }\end{array}$ & $\begin{array}{l}\text { Chicago Board Options } \\
\text { Exchange (CBOE) }\end{array}$ \\
\hline$W T$ & $\begin{array}{l}\text { The Working's T index is the ratio of speculative positions to total hedgers' } \\
\text { positions. It measures to what extent speculative positions exceed hedging } \\
\text { ones. Commercials are considered as hedgers and non-commercials as } \\
\text { speculators. }\end{array}$ & $\begin{array}{l}\text { Commodity Futures Trading } \\
\text { Commission (CFTC) }\end{array}$ \\
\hline
\end{tabular}

Notes: All variables are at weekly frequency, and are sampled on Tuesday.

Table 4 summarizes the definition and sources of the explanatory variables adopted in the second step of the econometric analysis. According to the Augmented Dickey Fuller (1979) unit root tests, all our explanatory variables are stationary or difference stationary. ${ }^{16}$

\subsection{Methods: A panel ARDL specification}

The second step in the econometric analysis allows flexibility in dealing with the characteristics of the DCCs, i.e. the time-series properties of the estimated correlations and the cross-sectional dimension.

Our dependent variables, being correlations, are bounded between -1 and +1 and are not normally distributed. To account for this feature, one possibility is to choose a limited dependent variable model. Alternatively, as we are dealing with correlations, we can adopt the Fisher transformation, which converts a correlation into a normally distributed variable. ${ }^{17}$

With a time span covering 16 years, an autoregressive distributed lag (ARDL) model is mostly suitable, as it reduces the bias in the long-run parameter estimates in finite samples. By choosing appropriate orders of lags in the ARDL model, it allows to correct for residual correlation as well as to tackle the presence of endogenous regressors (Pesaran and Shin, 1999). The latter feature is particularly noteworthy as some of our explanatory variables, i.e. speculation indexes, might not be exogenous. ${ }^{18}$

The second feature to handle is the cross-sectional dimension of the estimated DCCs. While a similar two-step approach has been adopted to investigate the single DCC between commodity and equity returns (Büyükşahin and Robe, 2014), we are modelling a panel of 45 DCCs between different commodity futures markets.

The traditional approach would be a dynamic fixed effects model (DFE), in which the time-series data for each of the 45 DCCs are pooled, and only intercepts are allowed to differ. Re-

16. The descriptive statistics and the unit root tests for the explanatory variables adopted in the ARDL analysis are reported in Table A.2 in the online Appendix.

17. Given a correlation $r$, the Fisher transformation is defined as $z=.5[\ln (1+r)-\ln (1-r)]$.

18. See the discussion on the definition of speculators in Section 3.1. 
cent developments in the dynamic panel data literature suggest, however, that the assumption of homogeneity of slope parameters is often inappropriate when dealing with a large- $\mathrm{N}$ large-T sample. Indeed, if slope coefficients are not identical, the DFE model produces inconsistent results, which are potentially misleading.

To relax this restriction, Pesaran and Smith (1995) proposed the mean-group (MG) estimator, which in our context estimates the model separately for each DCC and averages the coefficients, thus allowing the intercepts, slope coefficients, and error variances to differ across DCCs.

Subsequently, Pesaran et al. (1999) proposed the pooled mean-group (PMG) estimator, which relies on a combination of pooling and averaging of coefficients. The PMG model allows intercepts, short-run coefficients and error variances to differ across cross-sections, while imposing homogeneity only on the long-run coefficients.

While we might expect the long-run coefficients to be similar across DCCs, the reasons for assuming that short-run dynamics and error variances should be the same are less compelling, as commodities futures returns might react differently to shocks in the immediate future. On these grounds, we prefer a PMG model to the standard DFE. In such a case, however, estimates are efficient and consistent when the homogeneity restrictions on the long-run coefficients are true. If the hypothesis of slope homogeneity is empirically rejected and the true model is heterogeneous, the PMG estimates are inconsistent and the MG model instead provides estimates that are consistent in either case.

To choose between these two alternatives, we test the hypothesis of slope homogeneity by means of a Hausman test, which has a Chi squared distribution, with degrees of freedom equal to the number of coefficients being restricted in the long run, i.e. 15 in the present context. In our case the Hausman test on the hypothesis of slope homogeneity suggests that the PMG estimator, which we discuss hereafter, is to be preferred.

We estimate, by means of a PMG, an autoregressive distributive lag model $\operatorname{ARDL}(p, q)$ model:

$$
y_{i t}=\sum_{j=1}^{p} \alpha_{i j} y_{i t-j}+\sum_{j=0}^{q} \delta_{i j}^{\prime} X_{i t-j}+d_{i}+d y_{t}+d m_{t}+\varepsilon_{i t}
$$

where $i$ indexes the DCCs and ranges from 1 to $45 ; t$ is the week; $p$ is the number of lags of the dependent variable; and $q$ is the number of lags of the explanatory variables; $X_{i t-j}$ is a $k x 1$ vector of explanatory variables; $d_{i}$ is a time invariant DCC-specific effect; $d y_{t}$ are year dummies; $d m_{t}$ are month dummies, and the dynamic conditional correlations $y_{i t}$ range from 1 to $N$ over $T$ periods as $i=1, \ldots, 45$ and $t=1, \ldots, T$.

An advantage of the ARDL model is that it can be rewritten to display both the short- and the long-run coefficients. In this way, rather than focusing only on the short-run impact of our explanatory variables, we can easily read the long-run impact that is implied by the ARDL model. We thus express the model as follows:

$$
\Delta y_{i t}=\phi_{i}\left(y_{i t-1}-\theta_{i}^{\prime} X_{i t}\right)+\sum_{j=1}^{p-1} \alpha_{i j}^{*} \Delta y_{i t-j}+\sum_{j=0}^{q-1} \delta_{i j}^{*} \Delta X_{i t-j}+d_{i}+d y_{t}+d m_{t}+\varepsilon_{i t}
$$

where the parameter that defines the speed of adjustment to the long run is now equal to $\phi_{i}=-\left(1-\sum_{j=1}^{p} \alpha_{i j}\right)$, and the vector that contains the long-run coefficients is: $\theta_{i}=\sum_{j=0}^{q} \delta_{i j} /\left(1-\sum_{j=1}^{p} \alpha_{i j}\right)$. 
Additionally, $\alpha_{i j}^{*}=-\sum_{m=j+1}^{p} \alpha_{i m}$ with $j=1, \ldots, p-1$ and $\delta_{i j}^{*}=-\sum_{m=j+1}^{q} \delta_{i m}$ with $j=0,1, \ldots, q-1$. The vector $X_{i t-j}$ includes the set of explanatory variables discussed above. ${ }^{19}$ The lag length for $p$ and $q$ in the ARDL model is chosen following the Akaike and Schwarz information criteria, which both support an $\operatorname{ARDL}(1,1)$ specification. Thus, the equation we estimate boils down to:

$$
\Delta y_{i t}=\phi_{i}\left(y_{i t-1}-\theta_{i}^{\prime} X_{i t}\right)-\delta_{i 1}^{\prime} \Delta X_{i t-1}+d_{i}+d y_{t}+d m_{t}+\varepsilon_{i t}
$$

where $\phi_{i}$, the long-run speed of adjustment, simplifies to $-\left(1-\alpha_{i 1}\right)$; the vector of long-run coefficients is: $\theta_{i}=\left(\delta_{i 0}+\delta_{i 1}\right) /\left(1-\alpha_{i 1}\right)$; and $-\delta_{i 1}^{\prime}$ is the vector of short-run coefficients. Recall that the PMG model we estimate assumes homogeneity of coefficients for the long run, which implies that we end up with a vector of coefficients $\theta$.

The first differences of DCCs are thus regressed on the first lag of the DCCs in levels, to account for slow adjustment of the correlations, and on current and lagged first-differences of the explanatory variables. Since (4) is nonlinear in the parameters, it is estimated by the maximum likelihood method developed by Pesaran et al. (1999).

\subsection{Results: The PMG estimates}

Table 5.a reports the PMG estimates of an ARDL(1,1) model, more precisely the average of the short-run coefficients estimated for the different dynamic conditional correlations and the homogeneous long-run coefficients. ${ }^{20}$ We discuss, first, the whole set of dynamic conditional correlations, $D C C_{\text {all }}$ and then turn to the two subsamples of correlations which are of particular interest for the current academic and policy debate: those between energy and agriculture commodities, and those between energy and metals.

As expected, the coefficient $\phi_{i}$ is negative and significant across the three samples. The negative coefficient displayed by the $A D S$ in the long run suggests that the dynamic conditional correlations are larger in periods of worse economic conditions, which is consistent with the findings by Chow et al. (1999), Ji and Fan (2012), and Bhardwaj et al. (2015). Our results seem to provide evidence in favor of strengthening linkages between different commodity markets during periods of economic slowdown, which could be related to the observed shift of investors towards these markets, or to generalized shifts in the demand and supply for these commodities. ${ }^{21}$

Moving to the financial factors, we observe that the 3-month T-Bill (TB3) has a positive and significant coefficient in the long run, while not being statistically significant in the short run. This suggests that higher interest rates are associated with stronger dynamic conditional correlations between commodities. This result is found on the whole set of correlations, as well as on the energy-agriculture DCCs and the energy-metals ones. While a negative relationship between interest rates and real commodity prices is widely acknowledged in the literature (Frankel, 2006), the standard storable commodity pricing model by Deaton and Laroque $(1992,1996)$ suggests a positive

19. The series of the Working's T indexes are multiplied by a dummy variable equal to 1 for the corresponding cross-section, and zero otherwise, so that for each $i$ we include among the explanatory variables only the two WTs for the two commodities whose DCC we are considering.

20. The short-run coefficients specific for each dynamic conditional correlation $i$ are not reported, but are available from the authors on request.

21. As emerging economies have been recognized as a major driver of commodity demand in recent years, we provide a robustness check with a global measure of real economic activity in the online Appendix, Table A.4. 
Table 5.a: ARDL(1,1) - estimates

\begin{tabular}{|c|c|c|c|c|c|c|}
\hline \multirow[t]{2}{*}{ Panel A: estimates } & \multicolumn{2}{|c|}{ all commodities } & \multicolumn{2}{|c|}{ energy-agriculture } & \multicolumn{2}{|c|}{ energy-metals } \\
\hline & $\operatorname{LR}(\theta)$ & $\mathrm{SR}(\delta)$ & $\operatorname{LR}(\theta)$ & $\operatorname{SR}(\delta)$ & $\operatorname{LR}(\theta)$ & $\mathrm{SR}(\delta)$ \\
\hline$\phi$ & & $\begin{array}{c}-0.087 * * * \\
(0.003)\end{array}$ & & $\begin{array}{c}-0.089 * * * \\
(0.006)\end{array}$ & & $\begin{array}{c}-0.100 * * * \\
(0.006)\end{array}$ \\
\hline ADS & $\begin{array}{c}-0.012 * * * \\
(0.003)\end{array}$ & $\begin{array}{c}0.002 * * \\
(0.001)\end{array}$ & $\begin{array}{c}-0.014^{* *} \\
(0.006)\end{array}$ & $\begin{array}{c}0.002 \\
(0.002)\end{array}$ & $\begin{array}{c}-0.025 * * * \\
(0.007)\end{array}$ & $\begin{array}{c}0.003 \\
(0.003)\end{array}$ \\
\hline TB3 & $\begin{array}{c}0.014 * * * \\
(0.003)\end{array}$ & $\begin{array}{l}-0.001 \\
(0.001)\end{array}$ & $\begin{array}{l}0.011^{*} \\
(0.006)\end{array}$ & $\begin{array}{c}0.002 \\
(0.002)\end{array}$ & $\begin{array}{c}0.019 * * * \\
(0.007)\end{array}$ & $\begin{array}{c}0.004 \\
(0.003)\end{array}$ \\
\hline Spread & $\begin{array}{c}0.017 * * * \\
(0.003)\end{array}$ & $\begin{array}{c}-0.001 \\
(0.001)\end{array}$ & $\begin{array}{c}0.021 * * * \\
(0.005)\end{array}$ & $\begin{array}{l}0.002 * \\
(0.001)\end{array}$ & $\begin{array}{c}0.018 * * * \\
(0.006)\end{array}$ & $\begin{array}{c}0.003 \\
(0.002)\end{array}$ \\
\hline EX & $\begin{array}{c}0.669 * * * \\
(0.152)\end{array}$ & $\begin{array}{c}0.024 * * * \\
(0.006)\end{array}$ & $\begin{array}{c}0.379 \\
(0.306)\end{array}$ & $\begin{array}{c}0.034 * * * \\
(0.010)\end{array}$ & $\begin{array}{c}0.050 \\
(0.365)\end{array}$ & $\begin{array}{c}0.062 * * * \\
(0.018)\end{array}$ \\
\hline VIX & $\begin{array}{c}0.001 * * * \\
(0.000)\end{array}$ & $\begin{array}{c}-0.000 * * * \\
(0.000)\end{array}$ & $\begin{array}{c}0.002 * * * \\
(0.000)\end{array}$ & $\begin{array}{c}-0.000^{* *} \\
(0.000)\end{array}$ & $\begin{array}{c}0.001 * * * \\
(0.000)\end{array}$ & $\begin{array}{c}-0.000 * * * \\
(0.000)\end{array}$ \\
\hline WT WTI & $\begin{array}{c}0.262 * * \\
(0.111)\end{array}$ & $\begin{array}{c}-0.007 * * \\
(0.003)\end{array}$ & $\begin{array}{c}0.359 * * * \\
(0.137)\end{array}$ & $\begin{array}{c}-0.011^{* *} \\
(0.005)\end{array}$ & $\begin{array}{c}0.054 \\
(0.187)\end{array}$ & $\begin{array}{l}-0.006 \\
(0.005)\end{array}$ \\
\hline WT NG & $\begin{array}{c}0.205^{* * *} \\
(0.054)\end{array}$ & $\begin{array}{c}0.004 * * \\
(0.002)\end{array}$ & $\begin{array}{c}0.313 * * * \\
(0.074)\end{array}$ & $\begin{array}{c}0.010 \\
(0.007)\end{array}$ & $\begin{array}{c}0.094 \\
(0.079)\end{array}$ & $\begin{array}{l}0.013^{*} \\
(0.008)\end{array}$ \\
\hline WT corn & $\begin{array}{c}-0.134 * * * \\
(0.050)\end{array}$ & $\begin{array}{c}-0.006^{* *} \\
(0.003)\end{array}$ & $\begin{array}{r}-0.000 \\
(0.099)\end{array}$ & $\begin{array}{r}-0.006 \\
(0.004)\end{array}$ & & \\
\hline WT oats & $\begin{array}{c}0.038 \\
(0.034)\end{array}$ & $\begin{array}{c}0.000 \\
(0.001)\end{array}$ & $\begin{array}{c}0.213 * * * \\
(0.081)\end{array}$ & $\begin{array}{c}-0.003 \\
(0.002)\end{array}$ & & \\
\hline WT rice & $\begin{array}{c}0.071 * * * \\
(0.022)\end{array}$ & $\begin{array}{c}-0.002 * * * \\
(0.001)\end{array}$ & $\begin{array}{l}0.056^{*} \\
(0.034)\end{array}$ & $\begin{array}{c}-0.002 \\
(0.001)\end{array}$ & & \\
\hline WT soy & $\begin{array}{c}-0.159 * * * \\
(0.047)\end{array}$ & $\begin{array}{c}0.001 \\
(0.001)\end{array}$ & $\begin{array}{c}0.074 \\
(0.108)\end{array}$ & $\begin{array}{r}-0.005 \\
(0.004)\end{array}$ & & \\
\hline WT wheat & $\begin{array}{c}-0.088^{* *} \\
(0.041)\end{array}$ & $\begin{array}{c}-0.004 \\
(0.002)\end{array}$ & $\begin{array}{c}0.063 \\
(0.091)\end{array}$ & $\begin{array}{r}-0.010 \\
(0.006)\end{array}$ & & \\
\hline WT copper & $\begin{array}{c}0.059 * * \\
(0.027)\end{array}$ & $\begin{array}{c}0.001 \\
(0.001)\end{array}$ & & & $\begin{array}{c}0.037 \\
(0.052)\end{array}$ & $\begin{array}{l}-0.002 \\
(0.003)\end{array}$ \\
\hline WT gold & $\begin{array}{c}-0.063 \\
(0.040)\end{array}$ & $\begin{array}{c}-0.003 * \\
(0.001)\end{array}$ & & & $\begin{array}{c}-0.044 \\
(0.084)\end{array}$ & $\begin{array}{r}-0.006 \\
(0.007)\end{array}$ \\
\hline WT silver & $\begin{array}{c}0.063^{* * *} * \\
(0.024)\end{array}$ & $\begin{array}{c}0.001 \\
(0.001)\end{array}$ & & & $\begin{array}{c}0.069 \\
(0.044)\end{array}$ & $\begin{array}{c}0.002 \\
(0.002)\end{array}$ \\
\hline Constant & & $\begin{array}{c}0.004 \\
(0.004) \\
\end{array}$ & & $\begin{array}{c}-0.042 * * * \\
(0.004)\end{array}$ & & $\begin{array}{r}-0.010 \\
(0.007) \\
\end{array}$ \\
\hline $\mathrm{N}$ of LR restrictions & & & & & & \\
\hline Observations & & & & & & \\
\hline Log likelihood & & & & & & \\
\hline
\end{tabular}

Notes: Columns LR report the long-run coefficients $(\theta \mathrm{s})$, which refer to variables in levels, while the SR columns report the short-run coefficients $(\delta \mathrm{s})$, which refer to variables in first differences. All models include month and year dummies. *,**,*** denote statistical significance at the $1 \%, 5 \%$ and $10 \%$ levels, respectively; Standard errors are reported in parentheses.

relationship between interest rates and commodity volatilities. What then happens to commodity covariances and correlations depends on whether the effect of common or commodity-specific shocks prevails.

The positive coefficient for the Yield spread (Spread) suggests that in periods of higher premium for corporate bonds the correlations between commodities are larger. As the yield spread is known to be countercyclical (Hong and Yogo, 2012), this positive coefficient conveys a message coherent with that implied by the negative coefficient attached to the $A D S$ variable. This effect is confirmed for the subsamples of energy-agriculture and energy-metals DCCs.

Most international commodities are priced in U.S. dollars, and, as a consequence energy and non-energy commodity prices are affected by the U.S. dollar exchange rate (Hartley and Medlock III, 2014; Ji and Fan, 2012). The effect of the exchange rate $(E X)$ on correlations of energy and non-energy commodities depends on the degree to which these different futures markets react to 
the price changes induced by the exchange rates. The trade-weighted exchange rate $(E X)$ displays a positive and significant coefficient in Table 5.a, in both the short and in the long run. However, if we take a closer look, we find that in the panel of correlations between energy and agriculture and of those between energy and metals the statistically significant impact seems to be short-lived as it loses significance in the long run. Given the definition of the trade weighted U.S. dollar index provided by the Federal Reserve Bank of St. Louis, a stronger dollar is associated with larger correlations between energy and other commodities. ${ }^{22}$

The VIX displays a positive and significant coefficient in the long run, and a negative one in the short run. This is found also in the energy-agriculture and the energy-metals subsamples. There is a large literature on the relationship between uncertainty and economic outcomes. As discussed in Bloom (2014), uncertainty might indeed influence the economy differently across time horizons: several channels suggest a positive effect in the long run and a negative one in the short run. ${ }^{23}$ Joëts et al. (2017) also find non-linear responses over time of commodities prices and volatilities to uncertainty. Additionally, as VIX is countercyclical (Bloom, 2014), it is expected to display an opposite sign relative to ADS. Overall, financial factors appear to be relevant in understanding the dynamic conditional correlations between commodities futures returns.

The role of speculative activity on the volatility of commodity futures prices has attracted much attention in recent times. Recent empirical analyses have tested the effect of financial speculation on the returns and volatilities of commodities. ${ }^{24}$ Looking at correlations, Basak and Pavlova (2016) theoretically show that, if two or more commodities are part of the same asset class, traded perhaps as part of a commodity index, it is plausible to expect that extra financial activity will further increase their correlation beyond that already attributable to their product fundamentals. Tang and Xiong (2012) find that the increasing presence of index investors has led to larger return correlations between oil and other indexed commodities, while Bunn et al. (2017) show that speculation in the oil market increases the oil-gas correlation.

Our results show that speculative activity, measured by the Working's T indexes (WTS) in the different commodities markets, is generally statistically significant. With respect to energy commodities we observe that the WTs are positive and significant, with larger coefficients in the long run, thus suggesting that, as excess speculative activity increases in these futures markets, the dynamic conditional correlations with other futures markets increase as well. To draw some general conclusions, Panel b of Table 5 reports the tests for the joint significance of the WTs.

22. The results with an alternative definition of trade weighted U.S. Dollar index, also provided by FRED, are robust and are available from the authors on request.

23. For an insightful discussion of the different channels, we refer the reader to Bloom (2014). Very briefly, a negative relationship in the short run between uncertainty and economy can be derived from the "real options" argument and the "risk aversion and risk premia" argument. The real options argument suggests that uncertainty reduces the levels of investment, hiring and consumption, and encourages firms to become cautious about adjustment costs, while the risk aversion and risk premia argument suggests that, as greater uncertainty leads to increasing risk premia, investors want to be compensated for higher risk, and this raises the cost of finance. The positive expected relationship in the long run is suggested by the "growth options" argument and the "Oi-Hartman-Abel" effect. The "growth options" argument is based on the insight that uncertainty can encourage investment if it increases the size of the potential prize. The "Oi-Hartman-Abel" effect refers to the fact that firms can expand to exploit good outcomes and contract to insure against bad outcomes, thereby diminishing the potential impact of uncertainty. As argued by Joëts et al. (2017), these mechanisms can be reasonably extended to commodity markets.

24. Sanders and Irwin (2011), Irwin and Sanders (2012), and Manera et al. (2013) all conclude that speculation generally does not influence the returns of commodities. Manera et al. (2016) suggest that speculation is associated with lower volatility in energy markets, and Büyüksahin and Robe (2014) find that commodity-equity correlations rise amid greater participation by speculators. 
Table 5.b: ARDL(1,1) - tests

\begin{tabular}{|c|c|c|c|c|c|c|}
\hline \multirow[t]{2}{*}{ Panel B: Statistics } & \multicolumn{2}{|c|}{ all commodities } & \multicolumn{2}{|c|}{ energy-agriculture } & \multicolumn{2}{|c|}{ energy-metals } \\
\hline & $\operatorname{LR}(\theta)$ & $\mathrm{SR}(\delta)$ & $\operatorname{LR}(\theta)$ & $\mathrm{SR}(\delta)$ & $\operatorname{LR}(\theta)$ & $\mathrm{SR}(\delta)$ \\
\hline \multicolumn{7}{|l|}{ Joint significance test for WTs } \\
\hline Energy (2) & $\begin{array}{c}20.25 * * * \\
(0.000)\end{array}$ & $\begin{array}{l}8.31 * * \\
(0.016)\end{array}$ & $\begin{array}{c}25.05 * * * \\
(0.000)\end{array}$ & $\begin{array}{c}10.20 * * * \\
(0.006)\end{array}$ & $\begin{array}{c}1.51 \\
(0.469)\end{array}$ & $\begin{array}{l}7.80^{* *} \\
(0.020)\end{array}$ \\
\hline Agriculture (5) & $\begin{array}{c}35.14 * * * \\
(0.000)\end{array}$ & $\begin{array}{c}16.23 * * * \\
(0.006)\end{array}$ & $\begin{array}{l}10.60^{*} \\
(0.060)\end{array}$ & $\begin{array}{c}81.83 * * * \\
(0.000)\end{array}$ & & \\
\hline Metals (3) & $\begin{array}{c}14.11 * * * \\
(0.003)\end{array}$ & $\begin{array}{c}5.64 \\
(0.130)\end{array}$ & & & $\begin{array}{c}3.21 \\
(0.361)\end{array}$ & $\begin{array}{l}3.16 \\
(0.367)\end{array}$ \\
\hline \multicolumn{7}{|l|}{ Equality of coefficients test for WTs } \\
\hline Energy (1) & $\begin{array}{c}0.21 \\
(0.649)\end{array}$ & $\begin{array}{l}7.56^{* * *} \\
(0.006)\end{array}$ & $\begin{array}{c}0.08 \\
(0.773)\end{array}$ & $\begin{array}{l}9.08 * * * \\
(0.003)\end{array}$ & $\begin{array}{c}0.04 \\
(0.844)\end{array}$ & $\begin{array}{l}7.39 * * * \\
(0.007)\end{array}$ \\
\hline Agriculture (4) & $\begin{array}{c}35.14 * * * \\
(0.000)\end{array}$ & $\begin{array}{c}7.64 \\
(0.106)\end{array}$ & $\begin{array}{c}3.83 \\
(0.429)\end{array}$ & $\begin{array}{l}2.45 \\
(0.655)\end{array}$ & & \\
\hline Metals (2) & $\begin{array}{l}8.15^{* *} \\
(0.017)\end{array}$ & $\begin{array}{c}5.48^{*} \\
(0.065)\end{array}$ & & & $\begin{array}{c}1.44 \\
(0.486)\end{array}$ & $\begin{array}{c}3.01 \\
(0.222)\end{array}$ \\
\hline $\begin{array}{l}\text { Joint significance test for year } \\
\text { dummies (16) }\end{array}$ & \multicolumn{2}{|c|}{$\begin{array}{l}591.37 * * * \\
(0.000)\end{array}$} & \multicolumn{2}{|c|}{$\begin{array}{l}117.35 * * * \\
(0.000)\end{array}$} & \multicolumn{2}{|c|}{$\begin{array}{c}39.36 * * * \\
(0.000)\end{array}$} \\
\hline $\begin{array}{l}\text { Joint significance test for month } \\
\text { dummies (11) }\end{array}$ & \multicolumn{2}{|c|}{$173.74 * * *$} & \multicolumn{2}{|c|}{$\begin{array}{l}523.60^{* * * *} \\
(0.000)\end{array}$} & \multicolumn{2}{|c|}{$\begin{array}{c}12.94 * * \\
(0.000)\end{array}$} \\
\hline
\end{tabular}

Notes: All tests reported are $\mathrm{Chi}^{2}$ distributed. The number of degrees of freedom is reported in paretheses in the first column. Columns LR report tests on the long-run coefficients $(\theta \mathrm{s})$, which refer to variables in levels, while the SR columns report tests on the short-run coefficients $(\delta \mathrm{s})$, which refer to variables in first differences. $* * *, * * *$ denote statistical significance at the $1 \%, 5 \%$ and $10 \%$ levels, respectively.

The Wald tests for the joint significance of the speculative measures reveals that, in the full sample, WTs in energy, agriculture and metals futures markets are generally jointly significant, the only exception being the $W T s$ in metals in the short run. The test for the equality of coefficients assumes as the null hypothesis that the coefficients are statistically equal. This hypothesis is mostly rejected, which is not surprising, as we find both positive and negative statistically significant coefficients, i.e. there is not a uniform role of speculative activity. Interestingly, the test does not reject the null of equality of coefficients in the case of the WTs in energy markets in the long run, thus suggesting that speculative activity in the oil and natural gas markets convey the same message. Overall, the tests suggest that excess speculative activity in the energy markets, as measured by the Working's $T$ index, is positively related to dynamic conditional correlations between commodities.

To better understand the impact of excessive speculative activity on the correlations between energy and commodities from other industries, we focus on the two subsamples of DCCs of interest. Looking at the energy-agriculture DCCs, we find that larger values of the Working's T index in the energy and agriculture futures markets both correspond to higher correlations between these commodities. The Wald tests for the joint significance of the WTs reported in panel $\mathrm{b}$ of Table 5 confirms that speculative activity is significantly related to the energy-agriculture DCCs.

When we move to the energy-metals correlations instead, the results are not robust in the long run, as we lose the joint significance for both energy and metals WTs. Our results jointly suggest that, while WTs in energy markets are generally significant (see the results for the full sample), they are significant only when looking at the DCCs with agriculture rather than those with metal commodities.

With respect to speculative activity in metals, the joint significance of the WTs in the full sample disappears in the energy-metals subsample as a result of a compositional effect. Indeed, in the energy-metals subsample we are excluding some commodity pairs that are included in the "all commodities" estimates, for which we might expect WTs in metals to be significant, most notably 
the metal-metals DCCs. Overall, this suggests that the DCCs between energy and metals do not appear to be related to speculative activity in those markets. ${ }^{25}$

The annual dummies are not reported in order to save space. However, it is worth mentioning that, consistent with the findings described in the first step that the DCCs have been rising over time, they display positive and significant coefficients for the years immediately before and after the 2008 crisis, and have decreased thereafter. The test reported in Table 5.b shows that annual dummies are jointly statistically significant. Monthly dummies are significant as well, suggesting that seasonal effects are present in the DCCs.

\subsection{Robustness Analysis}

In this section we carry out some methodological robustness checks, while additional checks on the robustness of our results to alternative definitions of the explanatory variables are made in the online Appendix.

As a first check, we look at the estimates obtained following the traditional approach: namely, a DFE model. The results reported in Model (1) of Table 6.a are similar to those from our preferred specification, the PMG presented in Table 5.a.

Secondly, as the choice between the PMG and the MG estimators has been made on the basis of a Hausman test, we want to determine whether the results differ across these two models. We report the MG estimates in Table 6.a, Model (2): they are similar to the PMG estimates in Table 5.a, as well as to those of the DFE model reported in Table 6.a, Model (1). ${ }^{26}$

Thirdly, with respect to our dependent variable, we acknowledge in Section 2.2 that there are valuable alternatives to the DCC model, most notably, the BEKK. Thus, as a robustness check, we estimate a BEKK model and derive the time-varying correlations. We adopt these correlations as the dependent variable in the PMG model presented in Model (3) of Table 6. Again, the results are robust with respect to the main specification on all commodities reported in Table 5.a, suggesting that our findings do not rely on the methodology chosen to obtain the correlations. As discussed in Section 2.3, the time-varying correlations obtained from the BEKK and the dynamic conditional correlations from the DCC model are correlated 0.91 at the $1 \%$ significance level, and thus we could expect the robustness of the PMG estimates with this alternative dependent variable.

Finally, we check whether the frequency of our data might affect the results. Thus, we perform the analysis at monthly frequency and report the results in Model (4) of Table 6. Again, we can be confident that our results are robust. Further robustness checks with alternative explanatory variables which are only available at monthly frequency are discussed in the online Appendix.

\section{CONCLUSIONS AND POLICY IMPLICATIONS}

The links between energy and non-energy commodity futures markets have deepened in recent times. Theoretical and empirical analyses jointly suggest that the correlations between commodity futures, as well as the equity-commodity correlations, increase with the financialization of the commodity markets. The observed increase in the correlations between commodities has thus limited the benefits of such a diversification strategy (Basak and Pavlova, 2016; Cheung and Miu,

25. The results with alternative measures of trading activity in the commodity futures markets are discussed in the online Appendix.

26. Coefficient estimates for the WT of WTI are less significant in the DFE and MG models than in the PMG one. Although results are not exactly the same, joint tests of significance give the same conclusion. 
Table 6.a: ARDL(1,1) - Robustness checks - estimates

\begin{tabular}{|c|c|c|c|c|c|c|c|c|}
\hline \multirow[t]{2}{*}{ Panel A: estimates } & \multicolumn{2}{|c|}{ (1) } & \multicolumn{2}{|c|}{ (2) } & \multicolumn{2}{|c|}{ (3) } & \multicolumn{2}{|c|}{ (4) } \\
\hline & $\operatorname{LR}(\theta)$ & $\mathrm{SR}(\delta)$ & $\operatorname{LR}(\theta)$ & $\mathrm{SR}(\delta)$ & $\operatorname{LR}(\theta)$ & $\operatorname{SR}(\delta)$ & $\operatorname{LR}(\theta)$ & $\operatorname{SR}(\delta)$ \\
\hline$\phi$ & & $\begin{array}{c}-0.035 * * * \\
(0.001)\end{array}$ & & $\begin{array}{c}-0.098 * * * \\
(0.003)\end{array}$ & & $\begin{array}{c}-0.162 * * * \\
(0.006)\end{array}$ & & $\begin{array}{c}-0.229 * * * \\
(0.007)\end{array}$ \\
\hline ADS & $\begin{array}{c}-0.020 * * * \\
(0.007)\end{array}$ & $\begin{array}{c}0.001 \\
(0.001)\end{array}$ & $\begin{array}{c}-0.012 * * * \\
(0.003)\end{array}$ & $\begin{array}{c}0.002 * * \\
(0.001)\end{array}$ & $\begin{array}{c}-0.030 * * * \\
(0.010)\end{array}$ & $\begin{array}{c}0.008 \\
(0.006)\end{array}$ & $\begin{array}{c}-0.013 * * * \\
(0.004)\end{array}$ & $\begin{array}{c}0.002 * * \\
(0.001)\end{array}$ \\
\hline TB3 & $\begin{array}{c}0.023 * * * \\
(0.008)\end{array}$ & $\begin{array}{l}-0.001 \\
(0.001)\end{array}$ & $\begin{array}{c}0.012 * * * \\
(0.003)\end{array}$ & $\begin{array}{l}-0.001 \\
(0.001)\end{array}$ & $\begin{array}{c}0.053^{* * *} * \\
(0.010)\end{array}$ & $\begin{array}{l}-0.007 \\
(0.007)\end{array}$ & $\begin{array}{c}0.003 \\
(0.004)\end{array}$ & $\begin{array}{c}0.002 \\
(0.002)\end{array}$ \\
\hline Spread & $\begin{array}{c}1.987 * * * \\
(0.410)\end{array}$ & $\begin{array}{c}0.021 * * \\
(0.010)\end{array}$ & $\begin{array}{c}0.014 * * * \\
(0.003)\end{array}$ & $\begin{array}{l}-0.001 \\
(0.001)\end{array}$ & $\begin{array}{c}0.066^{* * *} \\
(0.009)\end{array}$ & $\begin{array}{l}-0.006 \\
(0.005)\end{array}$ & $\begin{array}{c}0.007 * * \\
(0.003)\end{array}$ & $\begin{array}{c}0.005 * * * \\
(0.001)\end{array}$ \\
\hline EX & $\begin{array}{c}0.028 * * * \\
(0.007)\end{array}$ & $\begin{array}{l}-0.000 \\
(0.001)\end{array}$ & $\begin{array}{c}0.700 * * * \\
(0.163)\end{array}$ & $\begin{array}{c}0.020 * * \\
(0.009)\end{array}$ & $\begin{array}{c}1.804 * * * \\
(0.519)\end{array}$ & $\begin{array}{c}0.155^{* * * *} \\
(0.041)\end{array}$ & $\begin{array}{c}2.211 * * * \\
(0.407)\end{array}$ & $\begin{array}{c}-0.324 * * * \\
(0.033)\end{array}$ \\
\hline VIX & $\begin{array}{c}0.001 * * \\
(0.000)\end{array}$ & $\begin{array}{c}-0.000 * * \\
(0.000)\end{array}$ & $\begin{array}{c}0.001 * * * \\
(0.000)\end{array}$ & $\begin{array}{c}-0.000 * * * \\
(0.000)\end{array}$ & $\begin{array}{c}0.004 * * * \\
(0.000)\end{array}$ & $\begin{array}{c}-0.001 * * * \\
(0.000)\end{array}$ & $\begin{array}{c}0.001 * * * \\
(0.000)\end{array}$ & $\begin{array}{c}-0.000^{*} \\
(0.000)\end{array}$ \\
\hline WT WTI & $\begin{array}{l}0.081^{*} \\
(0.044)\end{array}$ & $\begin{array}{c}0.007 \\
(0.006)\end{array}$ & $\begin{array}{c}0.014 \\
(0.022)\end{array}$ & $\begin{array}{c}-0.005^{*} \\
(0.003)\end{array}$ & $\begin{array}{c}0.331 \\
(0.396)\end{array}$ & $\begin{array}{l}-0.023 \\
(0.025)\end{array}$ & $\begin{array}{c}0.064 \\
(0.141)\end{array}$ & $\begin{array}{c}0.000 \\
(0.008)\end{array}$ \\
\hline WT NG & $\begin{array}{l}0.060 \\
(0.074)\end{array}$ & $\begin{array}{c}-0.017 * * * \\
(0.006)\end{array}$ & $\begin{array}{c}0.050 * * * \\
(0.017)\end{array}$ & $\begin{array}{l}0.004 * \\
(0.002)\end{array}$ & $\begin{array}{c}0.531 * * * \\
(0.188)\end{array}$ & $\begin{array}{c}0.038 * * \\
(0.019)\end{array}$ & $\begin{array}{c}0.261 * * * \\
(0.070)\end{array}$ & $\begin{array}{l}-0.006 \\
(0.005)\end{array}$ \\
\hline WT corn & $\begin{array}{l}-0.031 \\
(0.040)\end{array}$ & $\begin{array}{c}0.010 * * \\
(0.004)\end{array}$ & $\begin{array}{l}-0.040 \\
(0.025)\end{array}$ & $\begin{array}{c}-0.006^{*} \\
(0.003)\end{array}$ & $\begin{array}{c}-0.573 * * * \\
(0.171)\end{array}$ & $\begin{array}{c}-0.050^{* *} \\
(0.022)\end{array}$ & $\begin{array}{l}-0.081 \\
(0.061)\end{array}$ & $\begin{array}{c}-0.015^{*} \\
(0.008)\end{array}$ \\
\hline WT oats & $\begin{array}{c}-0.177 * * \\
(0.087)\end{array}$ & $\begin{array}{c}-0.029 * * * \\
(0.011)\end{array}$ & $\begin{array}{c}0.014 \\
(0.009)\end{array}$ & $\begin{array}{c}0.000 \\
(0.001)\end{array}$ & $\begin{array}{c}0.044 \\
(0.093)\end{array}$ & $\begin{array}{c}0.002 \\
(0.004)\end{array}$ & $\begin{array}{c}0.017 \\
(0.052)\end{array}$ & $\begin{array}{c}0.003 * * \\
(0.002)\end{array}$ \\
\hline WT rice & $\begin{array}{c}0.017 \\
(0.080)\end{array}$ & $\begin{array}{c}0.004 \\
(0.006)\end{array}$ & $\begin{array}{c}0.017 * * * \\
(0.006)\end{array}$ & $\begin{array}{c}-0.002 * * * \\
(0.001)\end{array}$ & $\begin{array}{c}0.230 * * * \\
(0.085)\end{array}$ & $\begin{array}{c}-0.016^{* *} \\
(0.007)\end{array}$ & $\begin{array}{c}0.009 \\
(0.034)\end{array}$ & $\begin{array}{c}-0.005^{* *} \\
(0.002)\end{array}$ \\
\hline WT soy & $\begin{array}{c}0.045 \\
(0.044)\end{array}$ & $\begin{array}{l}-0.004 \\
(0.006)\end{array}$ & $\begin{array}{l}-0.021 \\
(0.013)\end{array}$ & $\begin{array}{l}-0.000 \\
(0.001)\end{array}$ & $\begin{array}{c}-0.590 * * * \\
(0.165)\end{array}$ & $\begin{array}{c}0.002 \\
(0.009)\end{array}$ & $\begin{array}{c}-0.255^{* * *} \\
(0.061)\end{array}$ & $\begin{array}{r}-0.000 \\
(0.004)\end{array}$ \\
\hline WT wheat & $\begin{array}{c}-0.176^{*} \\
(0.096)\end{array}$ & $\begin{array}{l}-0.001 \\
(0.010)\end{array}$ & $\begin{array}{l}-0.015 \\
(0.013)\end{array}$ & $\begin{array}{l}-0.003 \\
(0.002)\end{array}$ & $\begin{array}{c}-0.332^{* *} \\
(0.131)\end{array}$ & $\begin{array}{c}-0.023^{* *} \\
(0.010)\end{array}$ & $\begin{array}{c}-0.065 \\
(0.054)\end{array}$ & $\begin{array}{c}-0.005^{*} \\
(0.003)\end{array}$ \\
\hline WT copper & $\begin{array}{l}-0.104 \\
(0.066)\end{array}$ & $\begin{array}{c}-0.020 * * * \\
(0.007)\end{array}$ & $\begin{array}{c}0.014 * * \\
(0.007)\end{array}$ & $\begin{array}{c}0.001 \\
(0.001)\end{array}$ & $\begin{array}{c}0.239 * * \\
(0.094)\end{array}$ & $\begin{array}{c}0.007 \\
(0.007)\end{array}$ & $\begin{array}{c}0.091 * * * \\
(0.032)\end{array}$ & $\begin{array}{l}0.003^{*} \\
(0.001)\end{array}$ \\
\hline WT gold & $\begin{array}{c}0.348 * * * \\
(0.134)\end{array}$ & $\begin{array}{c}-0.031 * \\
(0.016)\end{array}$ & $\begin{array}{l}-0.011 \\
(0.007)\end{array}$ & $\begin{array}{c}-0.003 * \\
(0.001)\end{array}$ & $\begin{array}{c}-0.063 \\
(0.151)\end{array}$ & $\begin{array}{c}-0.023^{* *} \\
(0.010)\end{array}$ & $\begin{array}{l}-0.054 \\
(0.063)\end{array}$ & $\begin{array}{c}-0.003 \\
(0.003)\end{array}$ \\
\hline WT silver & $\begin{array}{l}-0.018 \\
(0.038)\end{array}$ & $\begin{array}{c}0.037 * * * \\
(0.011)\end{array}$ & $\begin{array}{c}0.013 * * \\
(0.006)\end{array}$ & $\begin{array}{c}0.001 \\
(0.001)\end{array}$ & $\begin{array}{c}0.074 \\
(0.087)\end{array}$ & $\begin{array}{l}0.010^{*} \\
(0.006)\end{array}$ & $\begin{array}{c}0.034 \\
(0.035)\end{array}$ & $\begin{array}{c}0.002 \\
(0.001)\end{array}$ \\
\hline Constant & & $\begin{array}{c}0.002 \\
(0.003)\end{array}$ & & $\begin{array}{c}0.007 \\
(0.007)\end{array}$ & & $\begin{array}{c}-0.049 * * * \\
(0.016)\end{array}$ & & $\begin{array}{c}0.036 * * * \\
(0.011)\end{array}$ \\
\hline $\begin{array}{l}\mathrm{N} \text { of LR restrictions } \\
\text { Observations } \\
\text { Log likelihood }\end{array}$ & & & $\begin{array}{r}37 \\
112\end{array}$ & $\begin{array}{l}305 \\
50.3\end{array}$ & $\begin{array}{r}37 \\
441\end{array}$ & $\begin{array}{l}305 \\
45.76\end{array}$ & $\begin{array}{r}8, \\
231\end{array}$ & 320 \\
\hline
\end{tabular}

Notes: Model (1) presents the results obtained with the DFE estimator, while Model (2) presents the results obtained with the MG estimator. Model (3) presents the results with correlations obtained from a BEKK model as the dependent variable and Model (4) presents the results at monthly frequency. Columns LR report the long-run coefficients $(\theta \mathrm{s})$, which refer to variables in levels, while the SR columns report the short-run coefficients $(\delta \mathrm{s})$, which refer to variables in first differences. Models (1) - (3) include month and year dummies, and Model (4) year dummies only. $*, * * * * *$ denote statistical significance at the $1 \%, 5 \%$ and $10 \%$ levels, respectively; Standard errors are reported in parentheses.

2010; Daskalaki and Skiadopoulos, 2011). Understanding the dynamics of correlations between energy and non-energy futures markets is essential to develop accurate asset pricing models and hedging strategies, as well as to minimize the contagion risk on the occurrence of a crash in one of these markets (Baruník et al., 2015).

To this end, we estimate a DCC-GARCH model, to produce a set of dynamic conditional correlations between real weekly futures returns for oil, natural gas, and eight more commodities in the agriculture and metals markets from January 1998 to May 2014. The estimated DCCs are derived from a unique multivariate GARCH model, which allows us to discuss and compare the correlations between energy and agricultural commodities and those between energy and metals using a common framework. 
Table 6.b: ARDL(1,1) - Robustness checks - tests

\begin{tabular}{|c|c|c|c|c|c|c|c|c|}
\hline \multirow[t]{2}{*}{ Panel B: Statistics } & \multicolumn{2}{|c|}{ (1) } & \multicolumn{2}{|c|}{ (2) } & \multicolumn{2}{|c|}{ (3) } & \multicolumn{2}{|c|}{ (4) } \\
\hline & $\operatorname{LR}(\theta)$ & $\mathrm{SR}(\delta)$ & $\operatorname{LR}(\theta)$ & $\mathrm{SR}(\delta)$ & $\operatorname{LR}(\theta)$ & $\mathrm{SR}(\delta)$ & $\operatorname{LR}(\theta)$ & $\mathrm{SR}(\delta)$ \\
\hline \multicolumn{9}{|l|}{$\begin{array}{l}\text { Joint significance test } \\
\quad \text { for WTs }\end{array}$} \\
\hline Energy (2) & $\begin{array}{l}7.13 * * \\
(0.028)\end{array}$ & $\begin{array}{c}15.66 * * * \\
(0.000)\end{array}$ & $\begin{array}{c}9.37 * * * \\
(0.009)\end{array}$ & $\begin{array}{l}5.98 * * \\
(0.050)\end{array}$ & $\begin{array}{l}8.76 * * \\
(0.013)\end{array}$ & $\begin{array}{c}4.88^{*} \\
(0.087)\end{array}$ & $\begin{array}{c}14.17 * * * \\
(0.001)\end{array}$ & $\begin{array}{c}1.70 \\
(0.428)\end{array}$ \\
\hline Agriculture (5) & $\begin{array}{l}11.02 * * \\
(0.051)\end{array}$ & $\begin{array}{c}16.75 * * * \\
(0.001)\end{array}$ & $\begin{array}{c}20.45 * * * \\
(0.001)\end{array}$ & $\begin{array}{c}14.88^{* *} \\
(0.011)\end{array}$ & $\begin{array}{c}38.87 * * * \\
(0.000)\end{array}$ & $\begin{array}{c}18.41 * * * \\
(0.003)\end{array}$ & $\begin{array}{c}21.22 * * * \\
(0.001)\end{array}$ & $\begin{array}{l}14.54 * * \\
(0.013)\end{array}$ \\
\hline Metals (3) & $\begin{array}{c}4.60 \\
(0.203)\end{array}$ & $\begin{array}{c}15.44 * * * \\
(0.001)\end{array}$ & $\begin{array}{c}15.35 * * * \\
(0.002)\end{array}$ & $\begin{array}{c}4.99 \\
(0.172)\end{array}$ & $\begin{array}{l}7.23^{*} \\
(0.065)\end{array}$ & $\begin{array}{l}10.27 * * \\
(0.016)\end{array}$ & $\begin{array}{l}9.71 * * \\
(0.021)\end{array}$ & $\begin{array}{l}6.87^{*} \\
(0.076)\end{array}$ \\
\hline \multicolumn{9}{|l|}{$\begin{array}{l}\text { Equality of coefficients } \\
\quad \text { test for WTs }\end{array}$} \\
\hline Energy (1) & $\begin{array}{c}7.11 \\
(0.008)\end{array}$ & $\begin{array}{c}12.40 * * * \\
(0.000)\end{array}$ & $\begin{array}{c}1.55 \\
(0.213)\end{array}$ & $\begin{array}{l}5.91 * * \\
(0.015)\end{array}$ & $\begin{array}{c}0.20 \\
(0.651)\end{array}$ & $\begin{array}{l}3.64 * \\
(0.056)\end{array}$ & $\begin{array}{c}1.55 \\
(0.213)\end{array}$ & $\begin{array}{c}0.58 \\
(0.447)\end{array}$ \\
\hline Agriculture (4) & $\begin{array}{l}9.57 * * \\
(0.048)\end{array}$ & $\begin{array}{l}11.73 * * \\
(0.020)\end{array}$ & $\begin{array}{c}18.43 * * * \\
(0.001)\end{array}$ & $\begin{array}{c}5.45 \\
(0.245)\end{array}$ & $\begin{array}{c}36.54 * * * \\
(0.000)\end{array}$ & $\begin{array}{c}14.71 * * * \\
(0.005)\end{array}$ & $\begin{array}{c}15.88 * * * \\
(0.003)\end{array}$ & $\begin{array}{l}14.26 \\
(0.007)\end{array}$ \\
\hline Metals (2) & $\begin{array}{c}3.86 \\
(0.145)\end{array}$ & $\begin{array}{c}14.03 * * * \\
(0.001)\end{array}$ & $\begin{array}{c}10.13 * * * \\
(0.006)\end{array}$ & $\begin{array}{c}4.92 * \\
(0.085)\end{array}$ & $\begin{array}{c}3.37 \\
(0.186)\end{array}$ & $\begin{array}{l}8.76^{* *} \\
(0.013)\end{array}$ & $\begin{array}{c}4.62 * \\
(0.093)\end{array}$ & $\begin{array}{c}3.25 \\
(0.197)\end{array}$ \\
\hline $\begin{array}{l}\text { Joint significance test for } \\
\text { year dummies (16) }\end{array}$ & \multicolumn{2}{|c|}{$\begin{array}{c}181.60^{* * * *} \\
(0.000)\end{array}$} & \multicolumn{2}{|c|}{$\begin{array}{l}569.63 * * * \\
(0.000)\end{array}$} & \multicolumn{2}{|c|}{$\begin{array}{l}510.41 * * * \\
(0.000)\end{array}$} & \multicolumn{2}{|c|}{$\begin{array}{l}518.34 * * * \\
(0.000)\end{array}$} \\
\hline $\begin{array}{l}\text { Joint significance test for } \\
\text { month dummies (11) }\end{array}$ & \multicolumn{2}{|c|}{$\begin{array}{l}99.62 * * * \\
(0.000)\end{array}$} & \multicolumn{2}{|c|}{$\begin{array}{c}144.68 * * * \\
(0.000)\end{array}$} & \multicolumn{2}{|c|}{$\begin{array}{c}71.41 * * * \\
(0.000)\end{array}$} & & \\
\hline
\end{tabular}

Notes: All tests reported are $\mathrm{Chi}^{2}$ distributed. The number of degrees of freedom is reported in paretheses in the first column. Columns LR report tests on the long-run coefficients $(\theta \mathrm{s})$, which refer to variables in levels, while the SR columns report tests on the short-run coefficients $(\delta \mathrm{s})$, which refer to variables in first differences. $* * *, * * *$ denote statistical significance at the $1 \%, 5 \%$ and $10 \%$ levels, respectively.

We observe that the DCCs between the whole set of commodities, as well as between the subsamples of energy-agriculture and energy-metals commodities have increased in the months preceding the onset of the 2008 financial crisis and have fallen in the subsequent years. This first set of results is relevant, as it shows that dynamic conditional correlations increased sizably in a period of economic and financial turmoil. Overall, the DCCs between energy and metals are larger than the DCCs between energy and agriculture commodities.

However, this first evidence does not allow us to understand the circumstances which might have influenced such behaviour. Thus, in the second step of our econometric analysis, we estimate an ARDL $(1,1)$ model, choosing a PMG estimator to investigate which factors are related to these DCCs. We include in the model a set of macroeconomic, financial, and speculative activity variables.

The ARDL $(1,1)$ analysis reveals a number of interesting results. We find that the dynamic conditional correlations between energy-agriculture and energy-metals commodities are influenced by the macroeconomic fundamentals. Correlations between commodities futures markets are larger under weaker economic conditions. Larger correlations imply stronger connections between markets, and relatedly a higher risk of contagion in the event of a shock affecting one of them. Thus, according to the present evidence, financial markets regulators and investors should be warned that, in the face of an economic slowdown, the likelihood of contagion between these markets is larger.

The DCCs between commodities respond to financial markets conditions too. Notably, from a policy perspective, it is remarkable that higher volatility in markets (i.e. a larger VIX) is associated with larger DCCs in the long run, again signaling that linkages between these commodity futures markets that could eventually degenerate into episodes of contagion increase under more volatile markets. 
Focusing on the speculative activity in future markets, we find that excess speculation in the energy markets is associated with higher dynamic conditional correlations with agricultural commodities. Thus, careful attention should be paid to the activity of investors in these markets. Such a result is not found when considering instead the metals-energy dynamic conditional correlations.

These findings pose the question concerning whether the DCCs between energy and agriculture and between energy and metals have different behavior. While the first respond to macroeconomic, financial and speculative factors, the latter seem to react only to macroeconomic and financial conditions. Previous research generally focused on either the energy-agriculture or the energy-metals relationships, thus preventing a direct comparison of the factors which influence these correlations. In this contribution we analyze these dynamic conditional correlations over the same period of analysis, starting from a common specification, and considering the same explanatory variables, thus being in a better position to compare results and observe this discrepancy. The energy-metals DCCs are, on average, higher that the energy-agriculture ones, but speculative variables are significant only in the latter subsample of DCCs. Higher speculative activity in the energy markets is associated with stronger dynamic conditional correlations between energy and agriculture, but not between energy and metals. This supports the view that the links between energy and agricultural commodities have increased following a greater presence of non-commercial traders in the energy markets, a view that has stimulated from the 2000s abundant research on these links between the energy and agriculture future markets.

Given the evidence on the behavior of these DCCs over time, it would be interesting to further explore the structural break in the conditional correlations. Specifically, a relevant future research question could be to investigate the potential causes for the structural break in the relationships that go beyond the popular explanations, such as speculative activity. This is, however, beyond the scope of the present analysis, and leaves room for further research on this relevant issue.

\section{REFERENCES}

Alquist, R. and O. Gervais (2013). "The Role of Financial Speculation in Driving the Price of Crude Oil.” The Energy Journal 34(3): 35-54. https://doi.org/10.5547/01956574.34.3.3

Aruoba, S.B., F.X. Diebold, and C. Scotti (2009). "Real-Time Measurement of Business Conditions." Journal of Business and Economic Statistics 27(4): 417-27. https://doi.org/10.1198/jbes.2009.07205

Bhardwaj, G., G. Gorton, and G. Rouwenhorst (2015). "Facts and Fantasies about Commodity Futures Ten Years Later." NBER Working Paper No. 21243. https://doi.org/10.3386/w21243

Baruník, J., E. Kocenda, and L. Vácha (2015). "Volatility Spillovers Across Petroleum Markets.” The Energy Journal 36(3). https://doi.org/10.5547/01956574.36.3.jbar

Basak, S. and A. Pavlova (2016). “A Model of Financialization of Commodities.” Journal of Finance 71(4): 1511-1556. https://doi.org/10.1111/jofi.12408

Batten, J.A., C. Ciner, and B.M. Lucey (2010). "The macroeconomic determinants of volatility in precious metals markets." Resources Policy 35(2): 65-71. https://doi.org/10.1016/j.resourpol.2009.12.002

Bauwens, L., S. Laurent, S., and J.V.K. Rombouts (2006). "Multivariate GARCH models: A survey." Journal of Applied Econometrics 21: 79-109 https://doi.org/10.1002/jae.842

Bessembinder, H. and K. Chan (1992). "Time-varying risk premia and forecastable returns in futures markets.” Journal of Financial Economics 32(2): 169-193. https://doi.org/10.1016/0304-405X(92)90017-R

Bloom, N., (2014). "Fluctuations in uncertainty." Journal of Economic Perspectives 28: 153-176. https://doi.org/10.1257/ jep.28.2.153

Büyüksahin B., M.A. Robe (2014). "Speculators, Commodities and Cross-Market Linkages.” Journal of International Money and Finance 42: 38-70. https://doi.org/10.1016/j.jimonfin.2013.08.004

Bunn, D., J. Chevallier, Y. Le Pen, and B. Sevi (2017). "Fundamental and Financial Influences on the Co-movement of Oil and Gas Prices." The Energy Journal 38(2): 201-228. https://doi.org/10.5547/01956574.38.2.dbun

All rights reserved. Copyright $(2019$ by the IAEE. 
Caporin, M., M. McAleer (2012). "Do we really need both BEKK and DCC? A tale of two multivariate GARCH models." Journal of Economic Surveys 26(4): 736-751. https://doi.org/10.1111/j.1467-6419.2011.00683.x

Chang, T.H., H.M. Su (2010). "The substitutive effect of biofuels on fossil fuel in the lower and higher crude oil price periods.” Energy 35: 2807-2813. https://doi.org/10.1016/j.energy.2010.03.006

Charlot, P., V. Marimoutou (2014). "On the relationship between the prices of oil and the precious metals: Revisiting with a multivariate regime-switching decision tree.” Energy Economics 44: 456-467. https://doi.org/10.1016/j.eneco.2014.04.021

Cheng, I.H., W. Xiong (2014). "Financialization of commodity markets.” Annual Review of Financial Economics 6: 419-441. https://doi.org/10.1146/annurev-financial-110613-034432

Cheung, C.S., P. Miu (2010). "Diversification benefits of commodity futures." Journal of International Financial Markets, Institutions \& Money 20(5): 451-474. https://doi.org/10.1016/j.intfin.2010.06.003

Choi, K., S. Hammoudeh (2010). "Volatility behavior of oil, industrial commodity and stock markets in a regime-switching environment." Energy Policy 38: 4388-4399. https://doi.org/10.1016/j.enpol.2010.03.067

Chow, G., E. Jacquier, M. Kritzman, and K. Lowry (1999). “Optimal portfolios in good and bad times.” Financial Analyst Journal 55(3): 65-73. https://doi.org/10.2469/faj.v55.n3.2273

Colacito, R., R.F. Engle, and E. Ghysels (2011). “A Component Model for Dynamic Correlations.” Journal of Econometrics 164: 45-59. https://doi.org/10.1016/j.jeconom.2011.02.013

Daskalaki, C., G. Skiadopoulos (2011). "Should investors include commodities in their portfolios after all? New evidence." Journal of Banking \& Finance 35(10): 2606-2626. https://doi.org/10.1016/j.jbankfin.2011.02.022

Deaton, A., G. Laroque (1992). “On the Behaviour of Commodity Prices.” Review of Economic Studies 59(1): 1-23. https:// doi.org/10.2307/2297923

Deaton, A., G. Laroque (1996). "Competitive Storage and Commodity Price Dynamics." Journal of Political Economy 104(5): 896-923. https://doi.org/10.1086/262046

Dickey, D. A., W.A. Fuller (1979). "Distribution of the estimators for autoregressive time series with a Unit Root." Journal of the American Statistical Association 74: 427-431.

Du, X., C.L. Yu, and D.J. Hayes (2011). "Speculation and volatility spillover in the crude oil and agricultural commodity markets: A Bayesian analysis.” Energy Economics 33: 497-503. https://doi.org/10.1016/j.eneco.2010.12.015

Du, X., L.L. McPhail (2012). "Inside the Black Box: the Price Linkage and Transmission between Energy and Agricultural Markets.” The Energy Journal 33(2): 171-194. https://doi.org/10.5547/01956574.33.2.8

Engle, R.F., (2002). "Dynamic conditional correlation - a simple class of multivariate GARCH models." Journal of Business and Economic Statistics 20(3): 339-350. https://doi.org/10.1198/073500102288618487

Engle, R.F., (2009). Anticipating correlations. A new paradigm for risk management. Princeton University Press.

Engle, R., E. Ghysels, and B. Sohn (2013). "On the Economic Sources of Stock Market Volatility.” The Review of Economics and Statistics 95: 776-797. https://doi.org/10.1162/REST_a_00300

Engle, R.F., K.F. Kroner (1995). “Multivariate simultaneous generalized ARCH.” Econometric Theory 11: 122-150. https:// doi.org/10.1017/S0266466600009063

Ewing, B.T, F. Malik (2013). "Volatility transmission between gold and oil futures under structural breaks." International Review of Economics \& Finance 25: 113-121. https://doi.org/10.1016/j.iref.2012.06.008

FAO, (2008). "Soaring food prices: facts, perspectives, impacts and actions required." Proceedings of the high-level conference on world food security, Rome.

Frankel, J.A., (2006). "The Effect of Monetary Policy on Real Commodity Prices" in Campbell J. Y. (Ed.), Asset Prices and Monetary Policy, University of Chicago Press, 291-333.

Gardebroek, C., M.A. Hernandez (2013). "Do energy prices stimulate food price volatility? Examining volatility transmission between US oil, ethanol and corn markets." Energy Economics 40: 119-129. https://doi.org/10.1016/j.eneco.2013.06.013

Gorton, G., K. Rouwenhorst (2006). "Facts and fantasies about commodity futures." Financial Analyst Journal 62: 47-68. https://doi.org/10.2469/faj.v62.n2.4083

Hammoudeh, S., Y. Yuan (2008). "Metal volatility in presence of oil and interest rate shocks." Energy Economics 30: 606620. https://doi.org/10.1016/j.eneco.2007.09.004

Hartley, P. R., K.B. Medlock III, (2014). "The Relationship between Crude Oil and Natural Gas Prices: The Role of the Exchange Rate.” The Energy Journal 35(2): 25-44. https://doi.org/10.5547/01956574.35.2.2

Hong, H., M. Yogo (2012). "What does futures market interest tell us about the macroeconomy and asset prices?" Journal of Financial Economics 105: 473-490. https://doi.org/10.1016/j.jfineco.2012.04.005

Irwin, S.H., D.R. Sanders (2012). "Testing the masters hypothesis in commodity futures markets.” Energy Economics 34: 256-269. https://doi.org/10.1016/j.eneco.2011.10.008

Ji, Q., Y. Fan (2012). “How does oil price volatility affect non-energy commodity markets?” Applied Energy 89: 273 -280. https://doi.org/10.1016/j.apenergy.2011.07.038 
Joëts, M., V. Mignon, and R. Razafindrabec (2017). "Does the volatility of commodity prices reflect macroeconomic uncertainty?” Energy Economics 68: 313-326. https://doi.org/10.1016/j.eneco.2017.09.017

Karali, B., O.A. Ramirez (2014). "Macro determinants of volatility and volatility spillover in energy markets." Energy Economics 46: 413-421. https://doi.org/10.1016/j.eneco.2014.06.004

Kilian, L., D.P. Murphy (2014). "The Role of Inventories and Speculative Trading in the Global Market for Crude Oil." Journal of Applied Econometrics 29: 454-478. https://doi.org/10.1002/jae.2322

Levin, A., C.-F. Lin, and C.-S. J. Chu. (2002). “Unit root tests in panel data: Asymptotic and finite-sample properties.” Journal of Econometrics 108: 1-24. https://doi.org/10.1016/S0304-4076(01)00098-7

Manera, M., M. Nicolini, and I. Vignati (2013). "Financial speculation in energy and agriculture futures markets: a multivariate GARCH approach.” The Energy Journal 34(3): 55-81. https://doi.org/10.5547/01956574.34.3.4

Manera, M., M. Nicolini, and I. Vignati (2016). "Modelling futures price volatility in energy markets: Is there a role for financial speculation?” Energy Economics 53: 220-229. https://doi.org/10.1016/j.eneco.2014.07.001

Mensi, W., S. Hammoudeh, D.K. Nguyen, and S.M. Yoon (2014). "Dynamic spillovers among major energy and cereal commodity prices.” Energy Economics 43: 225-243. https://doi.org/10.1016/j.eneco.2014.03.004

Pagan, A., (1984). "Econometric Issues in the Analysis of Regressions with Generated Regressors." International Economic Review 25: 221-247. https://doi.org/10.2307/2648877

Pesaran, M.H., R. Smith (1995). "Estimating long-run relationships from dynamic heterogeneous panels." Econometrica 68(1): 79-113. https://doi.org/10.1016/0304-4076(94)01644-F

Pesaran, M.H., Y. Shin (1999). “An autoregressive distributed lag modeling approach to cointegration analysis.” In: Strom, S. (Ed.), Econometrics and Economic Theory in the Twentieth Century. Cambridge University Press, New York, NY. https:// doi.org/10.1017/CCOL521633230.011

Pesaran, M. H., Y. Shin, and R. Smith (1999). "Pooled mean group estimation of dynamic heterogeneous panels." Journal of the American Statistical Association 94(446): 621-634. https://doi.org/10.1080/01621459.1999.10474156

Sanders, D.R., S.H. Irwin (2011). "The impact of index funds in commodity futures markets: A systems approach.” The Journal of Alternative Investments 14: 40-49. https://doi.org/10.3905/jai.2011.14.1.040

Serra, T., (2011). "Volatility spillovers between food and energy markets: A semiparametric approach." Energy Economics 33: 1155-1164. https://doi.org/10.1016/j.eneco.2011.04.003

Silvennoinen, A., S. Thorp (2013). "Financialization, crisis and commodity correlation dynamics.” Journal of International Financial Markets, Institutions and Money 24: 42-65. https://doi.org/10.1016/j.intfin.2012.11.007

Sørensen, C., (2002). "Modelling seasonality in agricultural commodity futures." Journal of Futures Markets 22(5): 393426. https://doi.org/10.1002/fut.10017

Suenaga, H., A. Smith (2011). "Volatility dynamics and seasonality in energy prices: Implications for crack-spread price risk." The Energy Journal 32(3): 27-58. https://doi.org/10.5547/ISSN0195-6574-EJ-Vol32-No3-2

Tang, K., W. Xiong (2012). "Index investment and the financialization of commodities." Financial Analyst Journal 68(6): 54-74. https://doi.org/10.2469/faj.v68.n6.5

Trujillo-Barrera, A., M. Mallory, and P. Garcia (2012). "Volatility spillovers in the U.S. crude oil, ethanol, and corn futures markets." Journal of Agricultural and Resource Economics 73(2): 247-262.

Working, H., (1960). "Speculation on hedging markets." Food Research Institute Studies 1: 185-220.

Wu, H., S. Li (2013). "Volatility spillovers in China's crude oil, corn and fuel ethanol markets." Energy Policy 62: 878-886. https://doi.org/10.1016/j.enpol.2013.07.026

Wu, F., Z. Guan, and R.J. Myers (2011). "Volatility spillover effects and cross hedging in corn and crude oil futures." Journal of Futures Markets 31(11): 1052-1075. https://doi.org/10.1002/fut.20499 
Copyright of Energy Journal is the property of International Association for Energy Economics, Inc. and its content may not be copied or emailed to multiple sites or posted to a listserv without the copyright holder's express written permission. However, users may print, download, or email articles for individual use. 